件、推選各單位之科普代婊,現收到很函者,㖕 30 件, 昆

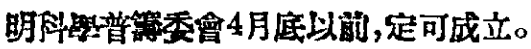

(䏁南日報 4月14日)

\section{3 旅大成立“科聯”分合籍委會}

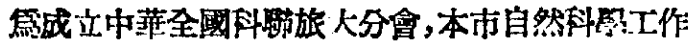

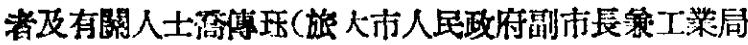

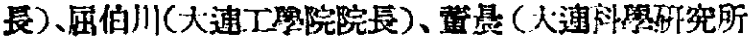

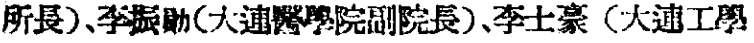

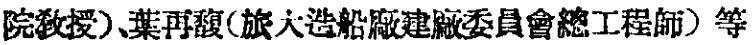

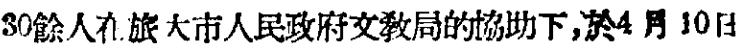

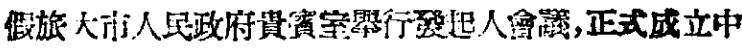

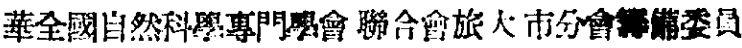

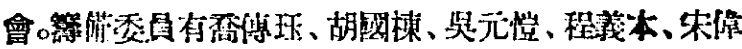

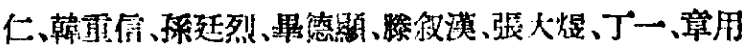

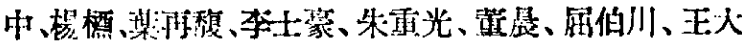

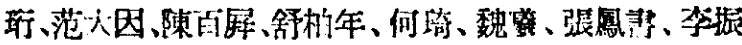

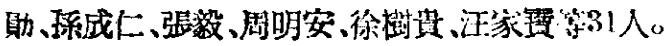

(旅人人民日報 4月14日)

\section{自然科學}

\section{1 最精磪的天拜}

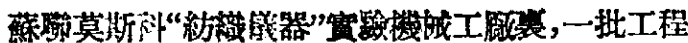
的和技的没訫出一種能种百萬分之一公分的精確大程。

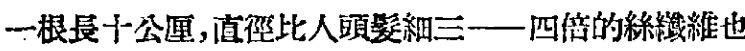
能科出它的雷盕。

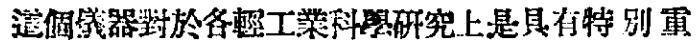

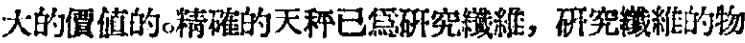

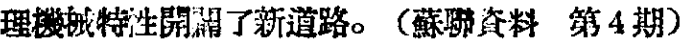

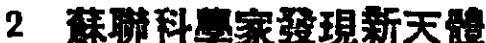

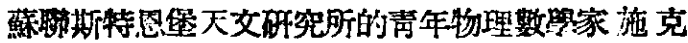
洛夫折基發現了一組新型的天體。施克洛夫斯基總結他

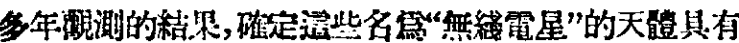

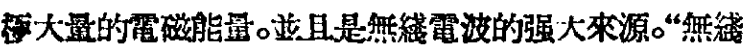

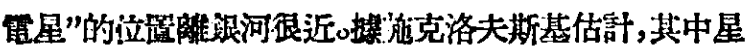
球的数目約鹪已發現的星球數目的十倍。

$$
\text { (新華社稿 } 4 \text { 月25日) }
$$

\section{3 大批星流連結銀河}

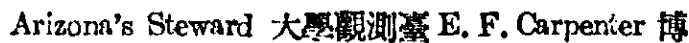
士上發現大批星流澾到許多成對旋渦銀河之間,每一個 星流初興我們的銀河同人。

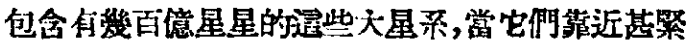
並形成宇宙“物合”時,即發展成气脣的速結。

Carpenter 博士利用36时的望違鏡覾測已進行歌多 年, 並包括有60到70銀河對; 它的観湘数於銀河組成的 方沠給一新的見解。它們之間的入流光或䠌狀物俰被潮

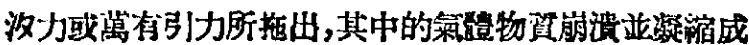
星䲕。

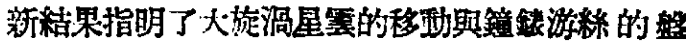

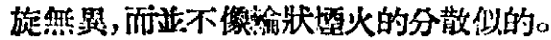

又在新發現的連祜中，兩個銀河的距襍何能很遠， 有眭光亦第走 100,000 年之久。

(Science News Letter 1051.1.27.)

\section{外之部}

\section{4 隤石科學的發暴}

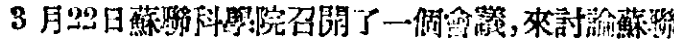

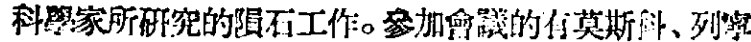

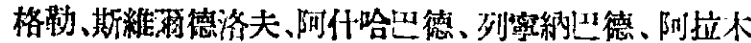

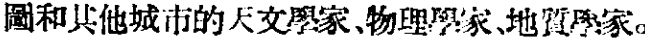

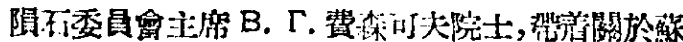

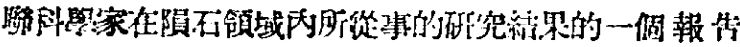

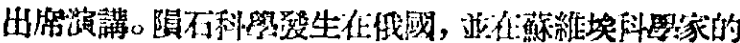

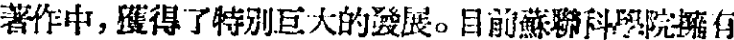

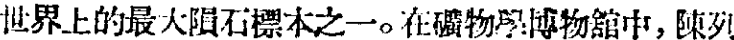

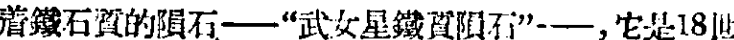

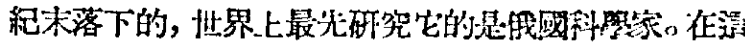

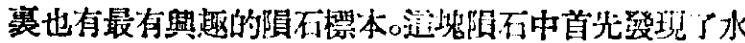

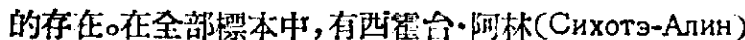

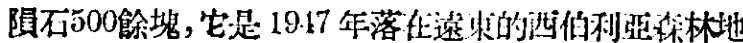
況 (Тайга) 中。

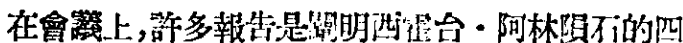
年來呼究總結。

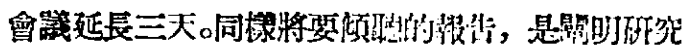

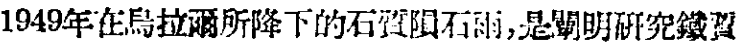

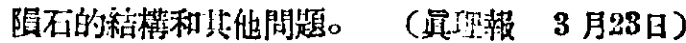

\section{5 日本的高頻率電之研究}

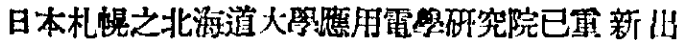

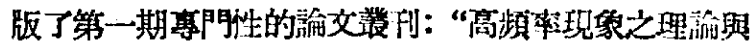
鹪用”，〔由淺見数授 (Y. Asami) 主編,1950年版，第

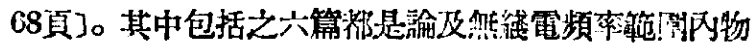
筫行票的。東 (K. Higasi) 與小摆 (Y. Ozawa) 二数

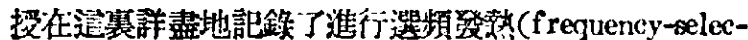

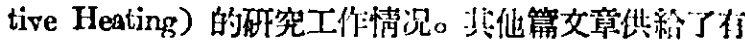

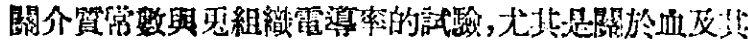

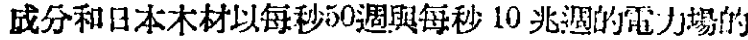

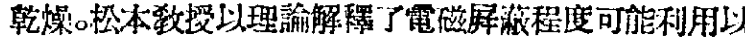

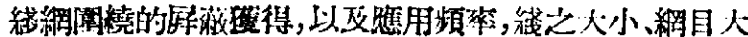

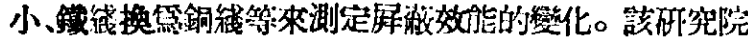

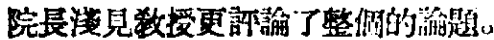

(Nature No. 4:95) 


\section{6 巴甫洛夫生理學問題會議}

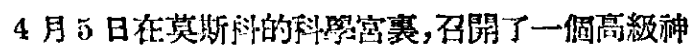

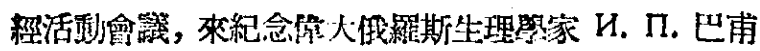

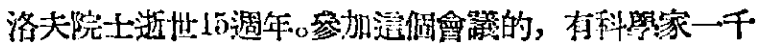

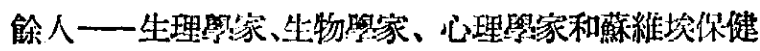
事赘家。

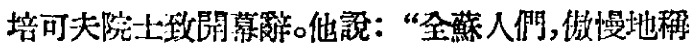

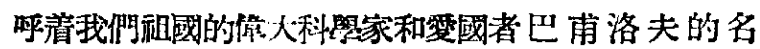
字。”

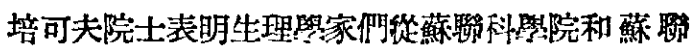

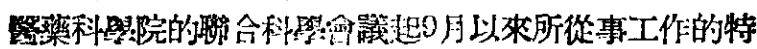

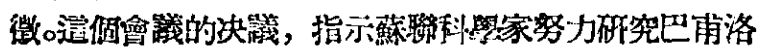
夫生理學的基本問題，大梘模地促潐科照研究，加强生

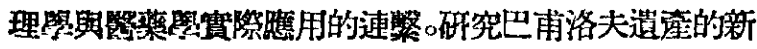
矼究所，不祗在我國建立起來，而且也在許多民主主䉝 國家內建立起來。

與此同時，培可夫院士並批評個別生理學家的命

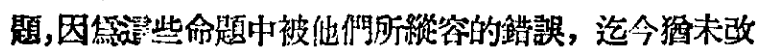
正。

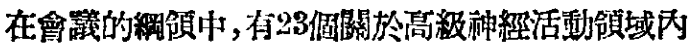
的新研究報告。

會議將延長謷天。（真理報 4 月 3 日）

\section{7 論 И. С. 別里塔什維䈪院 士的著作}

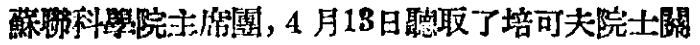

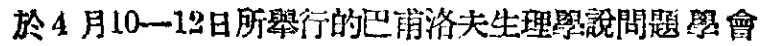

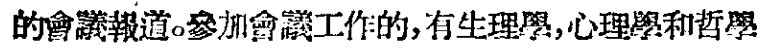
領域队的传秀專家。

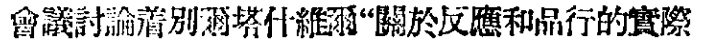

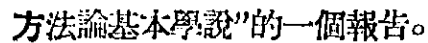

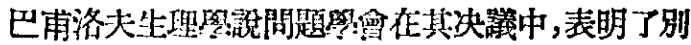

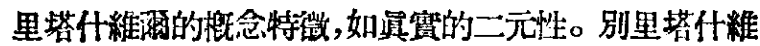

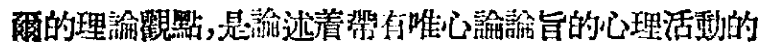
基本過程,佂原則上與巴甫洛夫關於高級神緸活射之合

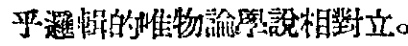

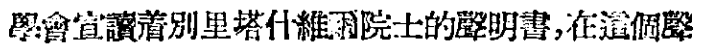

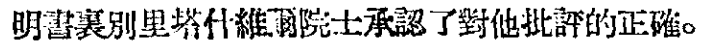

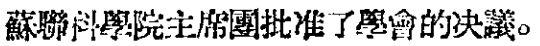

(真理報 4 月15日)

\section{8 可塑體代替了覆盖玻璃片}

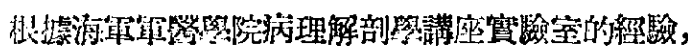

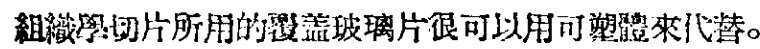

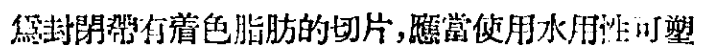

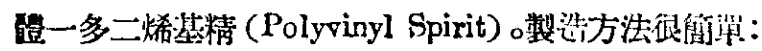

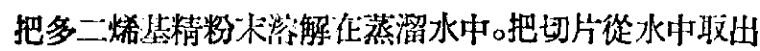

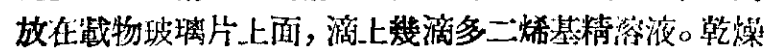

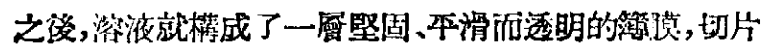
就封閉在敦面。

辈於用 Van Gieson 氏法或者蕉木紫做 (Hemat

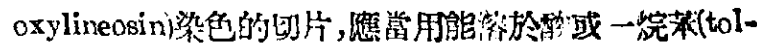

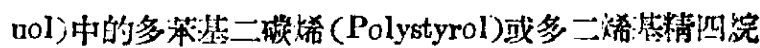

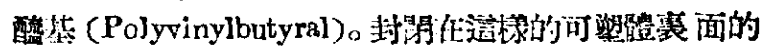

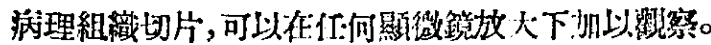

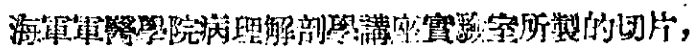

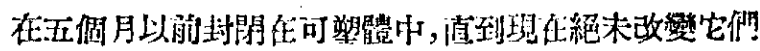

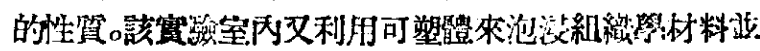
製作新的切片。此時也焦用多二烯装精。

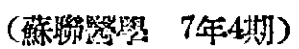

\section{9 冬季白暮中的維生素C}

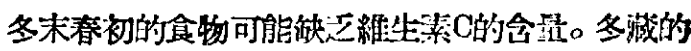

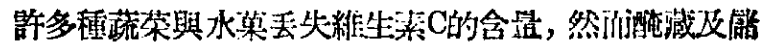
藏的白薯可保留高㽠的維生读C和維生素A。

(Science News Letter 1951.2.3.)

\section{0 水位浱落標誌量方地露的弡 生}

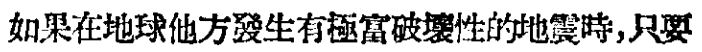

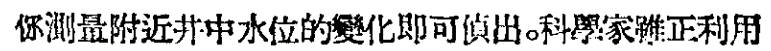

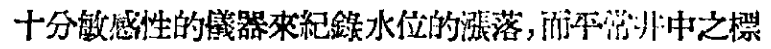

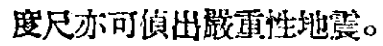

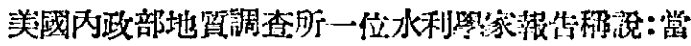

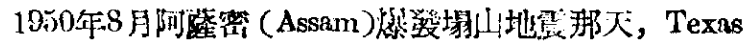

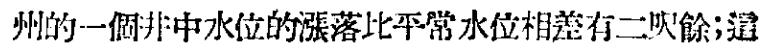

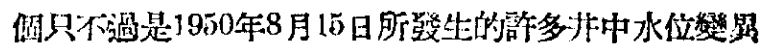
之一例。

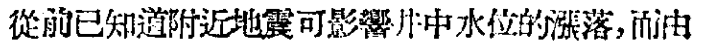

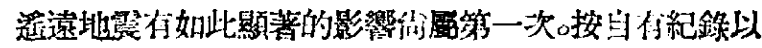

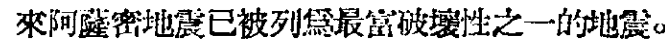

(Science News Letter 1951.1.20.)

\section{工業科學}

\section{1 蘇聯一工人弡明不䗒鎆自動 切割法}

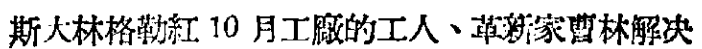

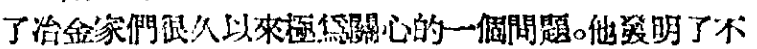

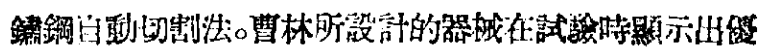

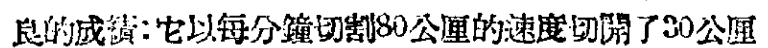

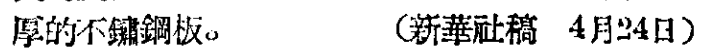

\section{2 球狀石壆鐇鐵的性芘和用途}

最近 A. B. Everest 曾在: Foundry Trade Journal

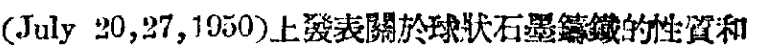

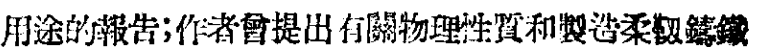

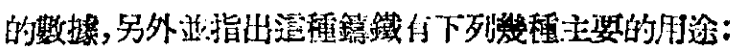

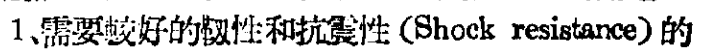
製件。

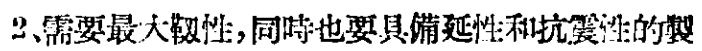
件。用於逜理場合時, 踓然所要求的泩能，可由等鐵的特 


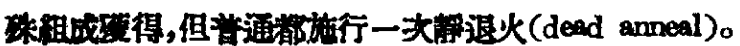

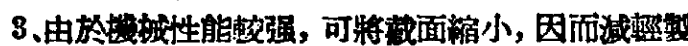
牛的面量。

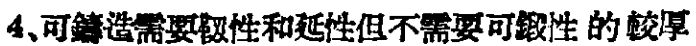
件。

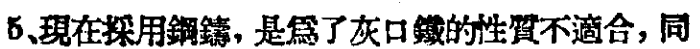

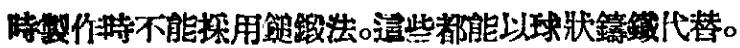

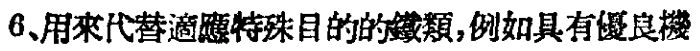

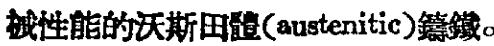

(東北科學通訊 1知10)

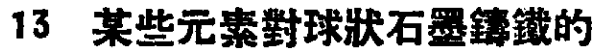 影势}

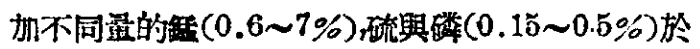

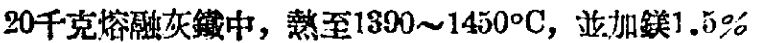

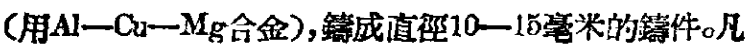

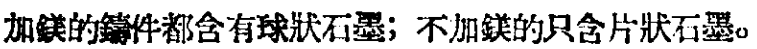

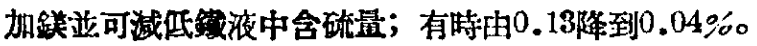
用含碳3.14，砤 $1.98 ，$ 銓 0.57 ，硫 0.14 與磷 $0.15 \%$ 的灰

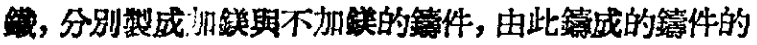
理性筫分列如下：抗張强度47.8，19.6千克1平方笔 米; 可化侮3.2,0.0\%;硬度Brinell 255,170。(復)

(東北科哭通訊 1经10期)

\section{4 步行偶送䇝}

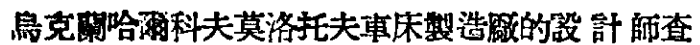
瓦德斯基同志發明了装琵機器用的一種步行傳洷機。逼

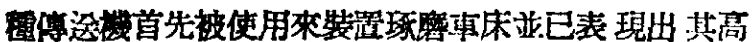

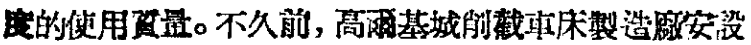
了一部步行棈遥機。

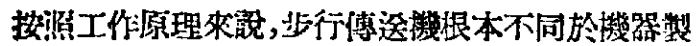

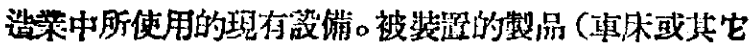

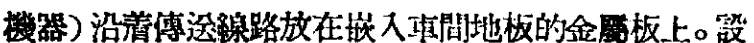
於地板內的水力起重機钢過一定的時間把徝休或機器 促地面提迎雨公分到雨公分牛，而另一種機栈則使它們

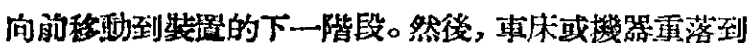
地面。

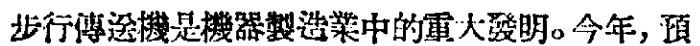

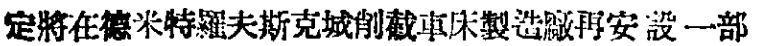

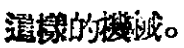

（實話報 4月19日）

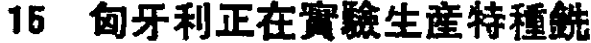 鏡的新方法}

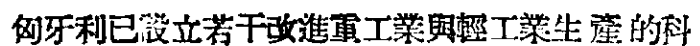

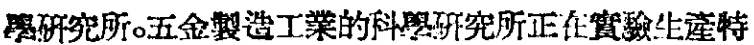

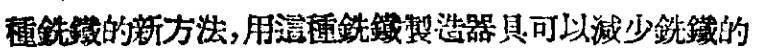
渭耗沮 $30-60 \%$

(光明日啹5月14日)

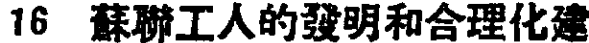
議

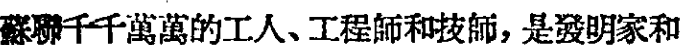

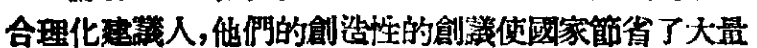

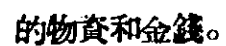

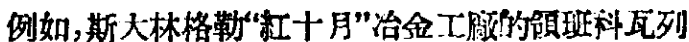

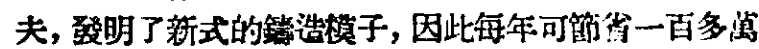
布。

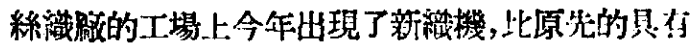

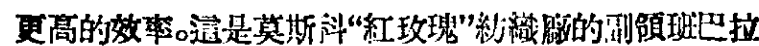

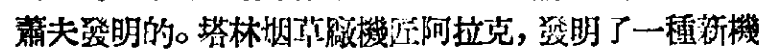

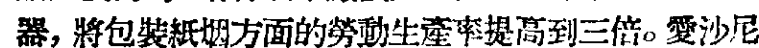

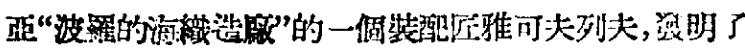

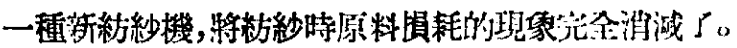

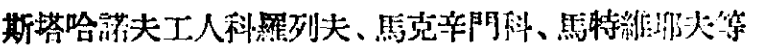

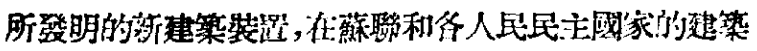

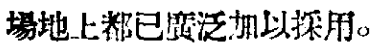

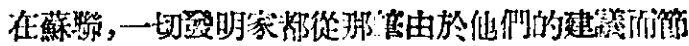

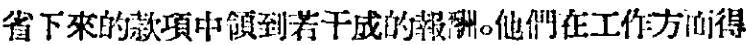

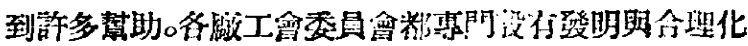
促進部。

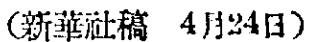

\section{7 羅馬尼亞最大的鼓風蕾開工}

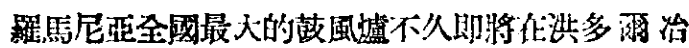

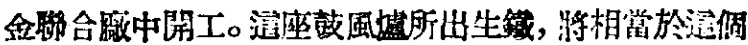

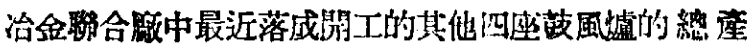

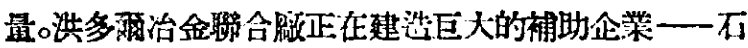

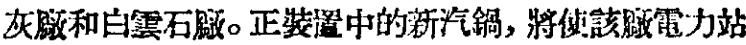

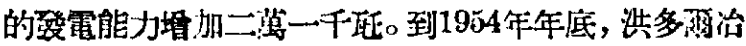

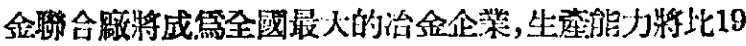
50 年提高一倍。

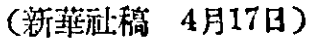

\section{8 在柴姆梁斯卡雅水利工程的 建築現暢上}

柴姆梁斯卡雅全禽水利工程中的土堤正任利用水

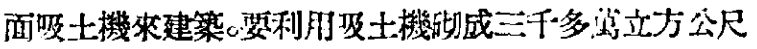
的土堤。

目鸽，在土堤的建築中，使用儿部吸土機。夏季期間， 吸士機的数目將境至㖣。土堤的建策中所使用的吸士 機有雨種類型，一種每小時吸士量你三百立方公尺，另

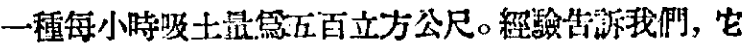

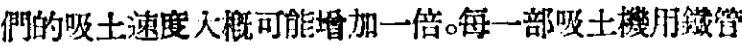

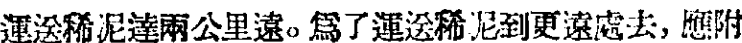
没一些抽水站, 早已建成十佃抽水站,現任, 又建妚厂一 㑑啲水站。

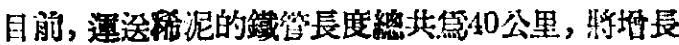
到一百公里。

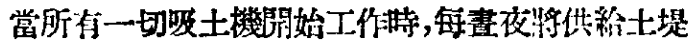

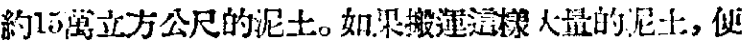

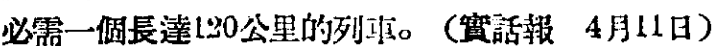

\section{9 巨型載重汽車}

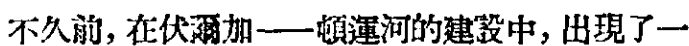

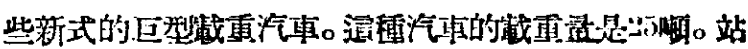

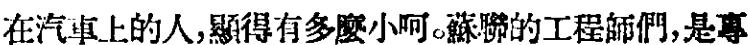

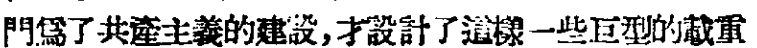

- 682 •

科學通報

第二卷 
F㫫的。

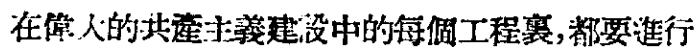
大規模的舑土工作。要從某些地方, 用機器的力量, 把幾 百萬顿的泥士，運到另外的地方去。

開警機把三立方米的土，一层斗抓起來。司機按着

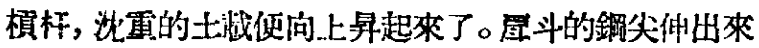

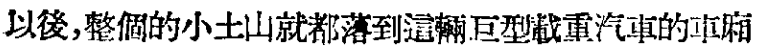

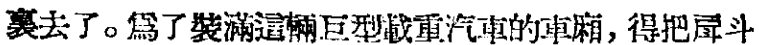

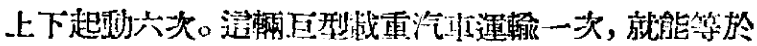

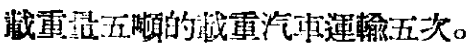

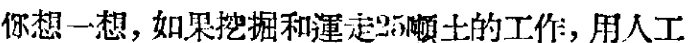

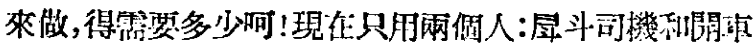

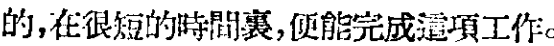

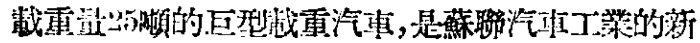

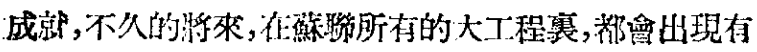

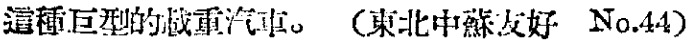

\section{0 世界上最高的大樓}

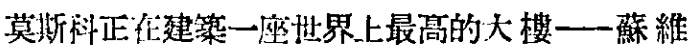
埃窝。它的總高度将有 1,300 吹, 比目前比界上的最简建

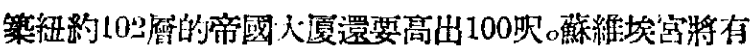

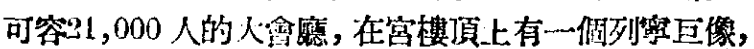
不部侖從那一㑑方向來到莫斯科,都將在十幾哩外就可以 看到那㕸巨人。

（蘇聯资料 第4期）

\section{1 保加利亞的建築工程}

保㧅利亞以席大渭模進行鐵路的建策工作。最近五 年以來，七條渐鐵路都通功了。通幾條鐵路將從命落後

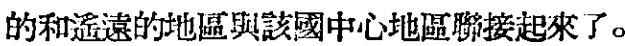

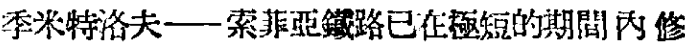
建完竣。

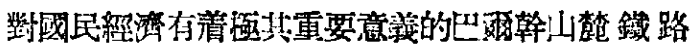
的建築工程以加速的速度淮行着。今年年底遥一建築工

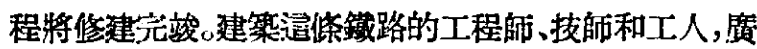

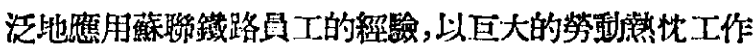
着。

新鐵路線将幫助國家更克分的利用其生产力, 並且

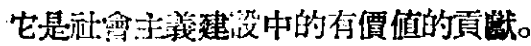

保吅利留勞動人民任社會主義建設戰綫。上檴 得了

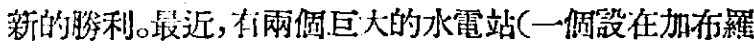

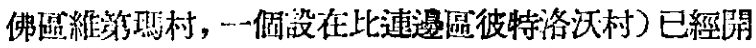
始發電。

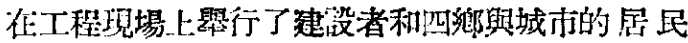
大會。電深部部長金蒙・格奥渌格耶夫、該建築工程的總 工程師、突繁豚冒、佂會人士代表均在維第玨水電站的 隆雷閉募典福中役表了演講。

在度视彼特洛沃水電站開始發電的大會上, 保加利

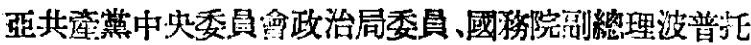
莫夫代表政府和保共中央委員冾對蘚聯和捷克斯洛伐

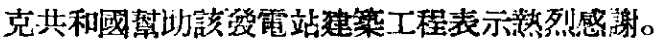

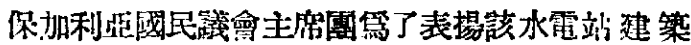
工程卓越成就的工作者，特授予黝音、獎音和榮 礐獎
狀。

（货話報 4 月13日）

\section{2 波菊的石油工業}

解放後波闌的石油工業一一和其他工業一栈一大 多数均被破壤洏需要大量的投資。

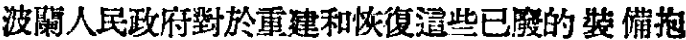
有極大的信心。他們探用了蘇聯有經踰的莎式探油法來 代替蚫式方法。

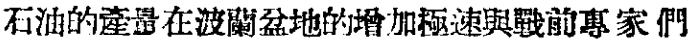
的意見㭘好相反。

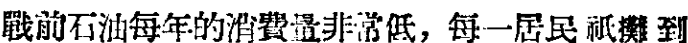
$13.7 \mathrm{~kg}$, 到1947年埇加到 $19 \mathrm{~kg}$ 。

總而言之,在戰的每一居民每年不泊繁品用量是很 低的,其中 $4 \mathrm{~kg}$ 是沼明用的。由於村落雷力使用的發達， 在19.48年每一屈民照时用不油沙费唯下降至。.4kg。

在 1955 年將要有 80,700 架掉拉機(每1 拖拉機 15 飞馬力)出现佂波闌的田野上㙅作。29\%的貨物將用汽

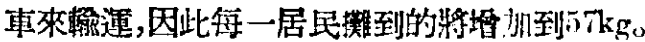

波蘭六年計劃，預期每年從鑛石提出的不油堆加到 394, 000傾。

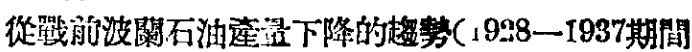

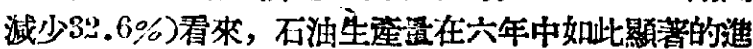
展是一個饩困難的目㯲。

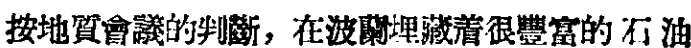

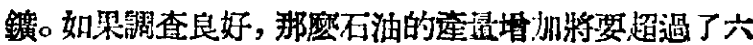
年計劃中所規定的。

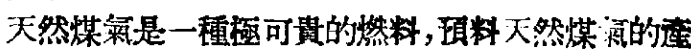

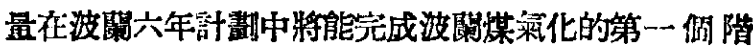
段。

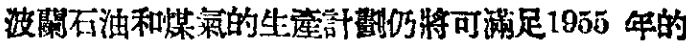
需要, 踓然需要显比 1949 年增加得多了。同時從萑和

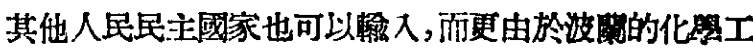

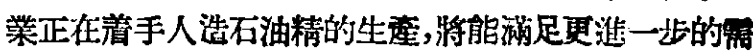
要。

(Polish Bulletin No.38)

\section{3 柏油混凝土道路鋪裝機}

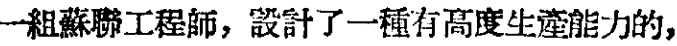

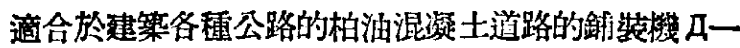
$150 \mathrm{~A}$ 。

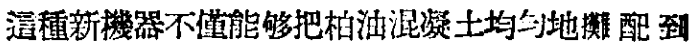
道路、上法，還能預光把它推平。

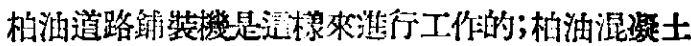

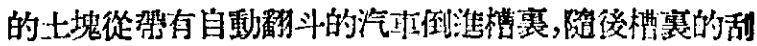

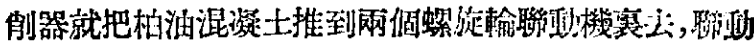

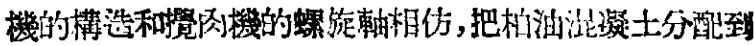
道路的整個寬幅上去,柏油層的厚度可以從 15 公厘到15

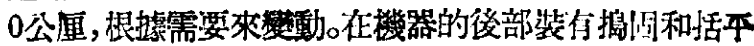

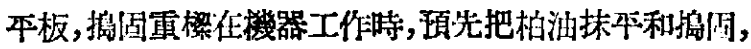

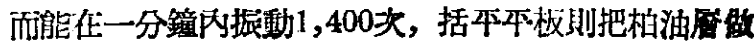
進一步的捣篮。

聯合機器是獨立移動的，蓝在自己的後部留下一俈 覆以柏油混合物的,宽達三米以上的平坦的道路。 


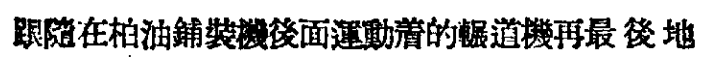
把道路推固。'

A-150A刑機器以每分鐘 7 米的速度向前運動, 向後運動的速度是每分鐘 8 米。它能代替大福工人和消

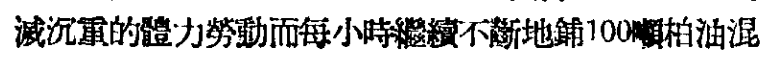
凝土。

(東北中蘇父好 No.44,)

\section{4 最新式的建築防水堤骦法}

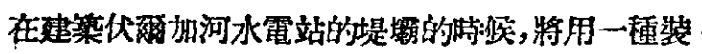

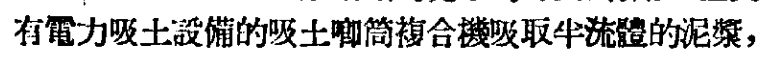

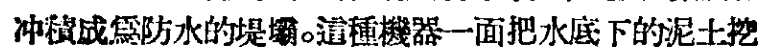
筑, 一面又把通些泥土用强有力的路心吸土哪筒吸䞟

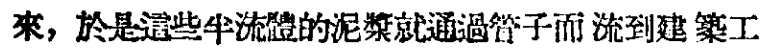

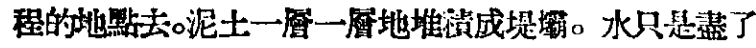

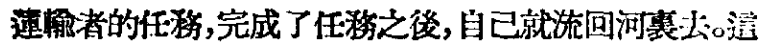

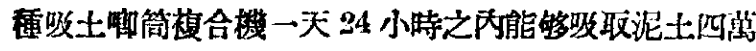
相，满到三、四公里以外的地方。

$$
\text { （箖玹資料 第4期） }
$$

\section{5 栔式的火柴}

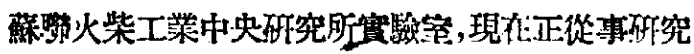
一種能在各種場合一一不受氣侯、溫度風利水的限泚使 用的新式火柴。

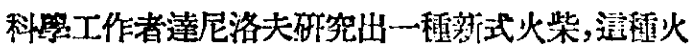

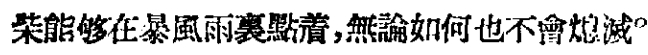

一等科淟工作者，馬洛柯夫研究出一種比普通火柴

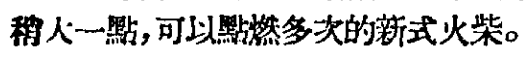

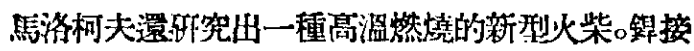

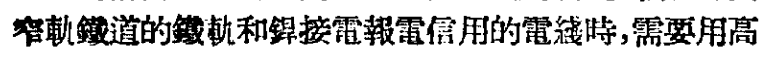

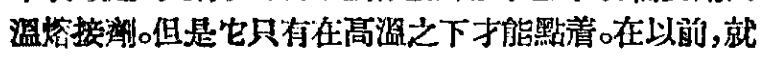
必須使用電弧才行。造是很困蜼的，尤其是在離居民中

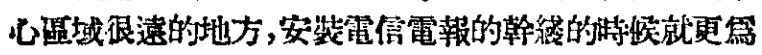
因難。馬洛柯夫研究出的新火柴, 它墢出非赏高的温度,

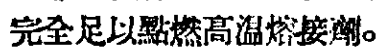

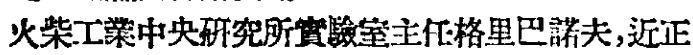

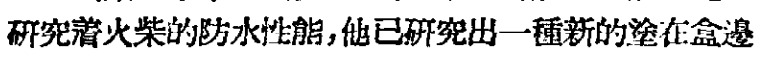

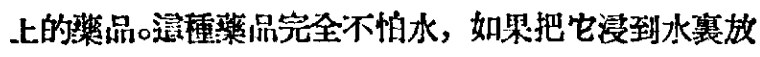

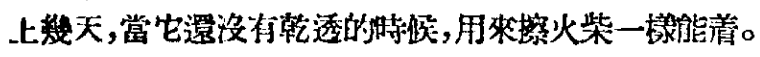

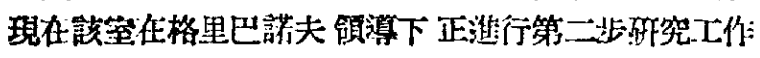

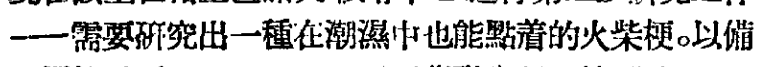
人們的需要。

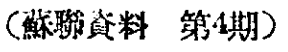

\section{6 体饰科學家䓡加共産主義建 設工程}

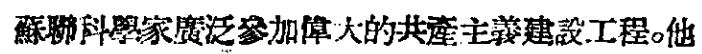

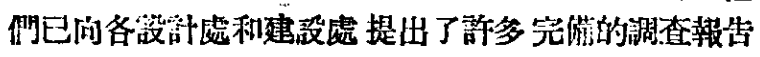
與建㼁。

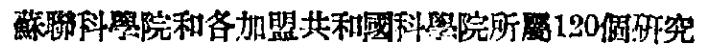

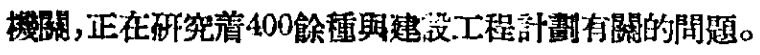

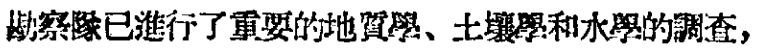

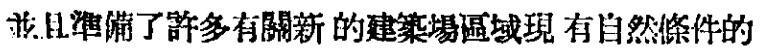

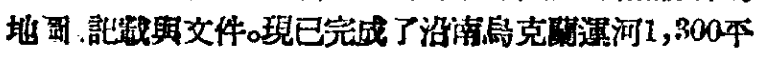

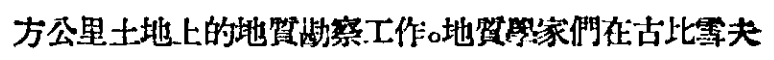

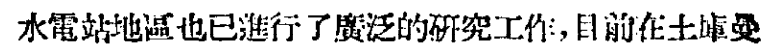

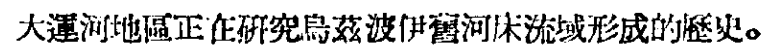

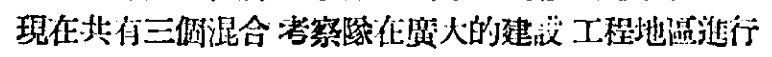
研究。

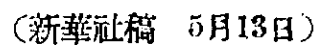

\section{7 葆㛵科學與生座合作運動蓄 滬展開}

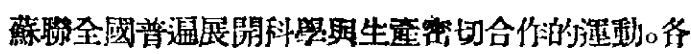

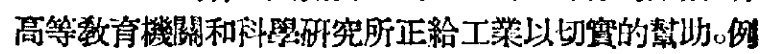

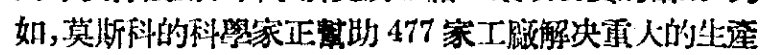
問題。莫斯科航空研究所的数授研究出一種分析合全的

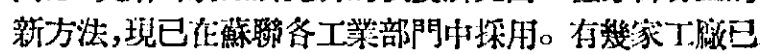

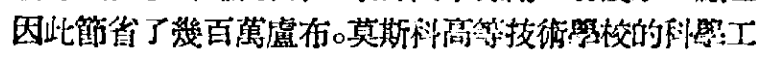

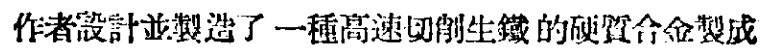

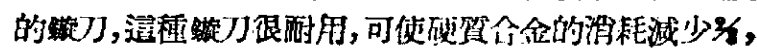

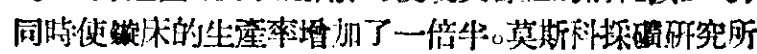

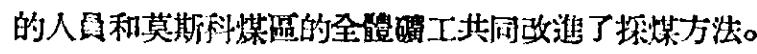

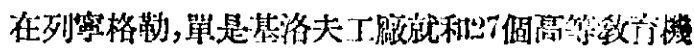

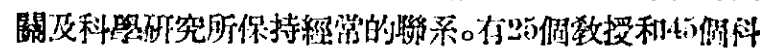

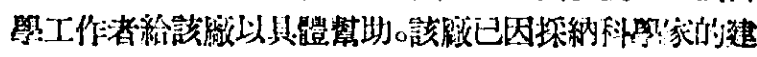

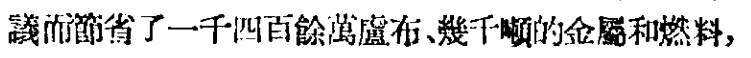

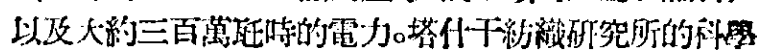

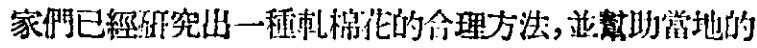

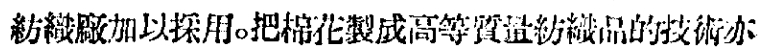

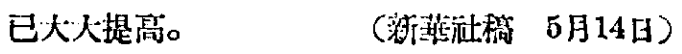

\section{㻃柴科學}

\section{8 匈牙利改造自然工作}

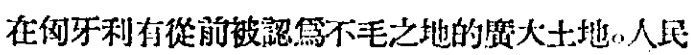

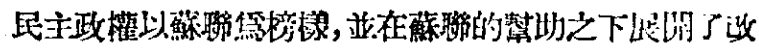

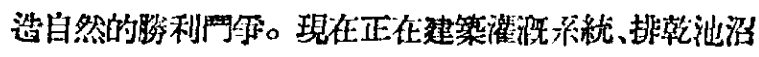

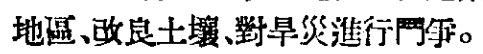

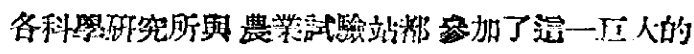

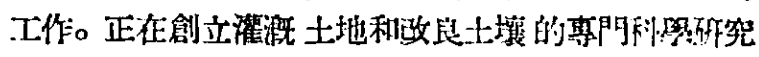

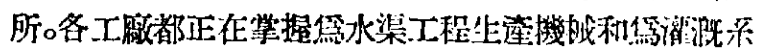

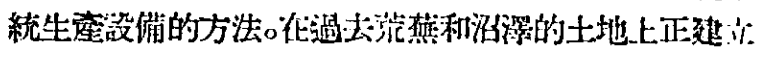

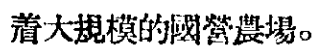

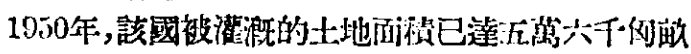

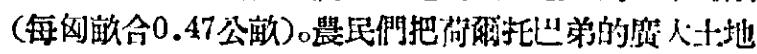

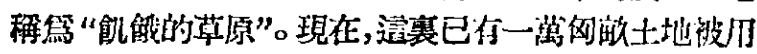

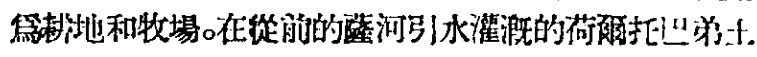

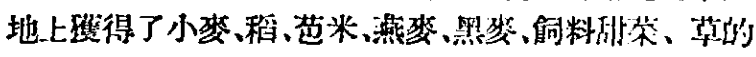

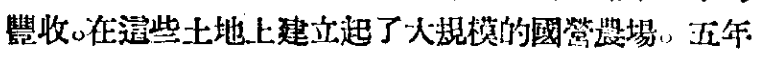

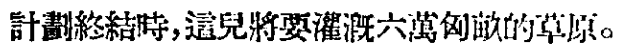

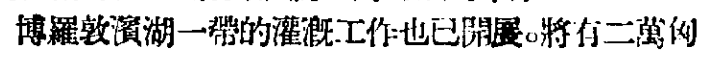

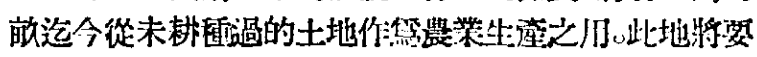

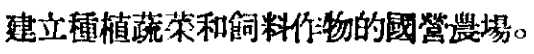

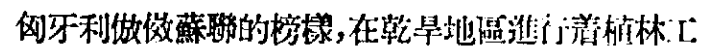

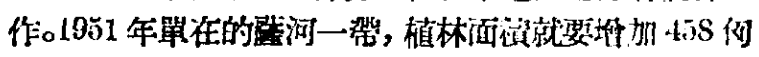
- 684 •
科學通報
第二卷 
解。

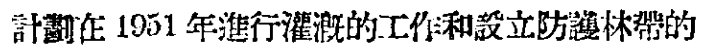

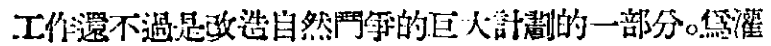

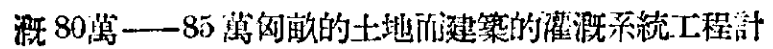

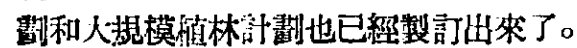

（質話報 4 月6日）

\section{9 防止散黑壃病的新方法}

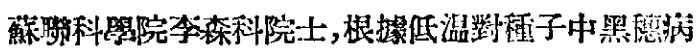

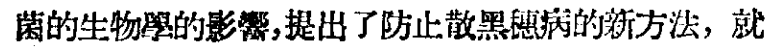
是:晚秋播種。

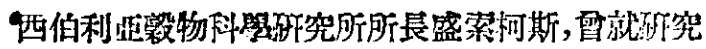

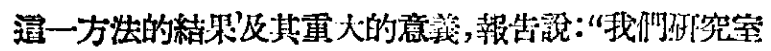

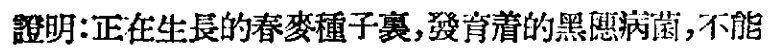

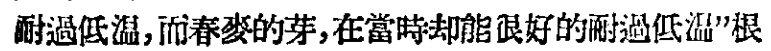

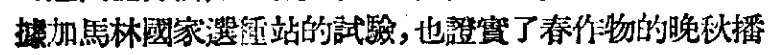

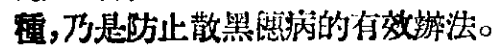

\section{(東北農業 No.25)}

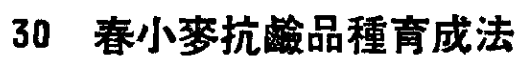

用米邱林式的方法, 來改變小麥的本性, 使之適合

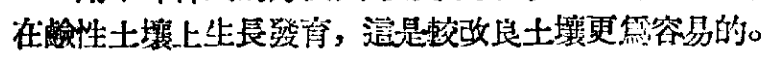

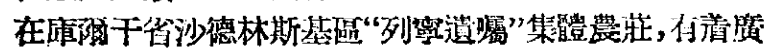

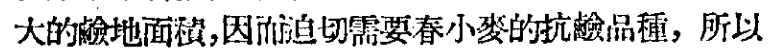
我們决定代决邱林一一李森科學諰的指導下，用自己的 力皆來㨦得这栐品種。

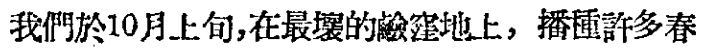

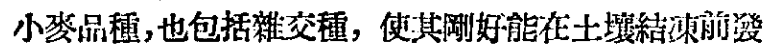
芽。

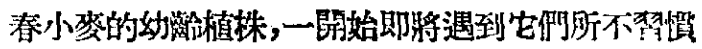

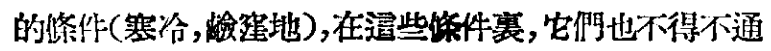

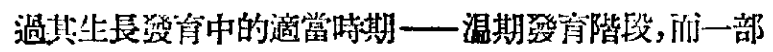

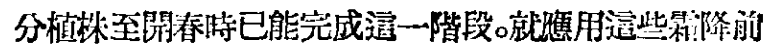

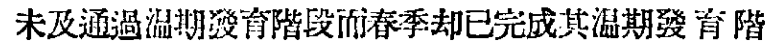
段的春小嘜植株,來進行改變其本性的工作，用培育的

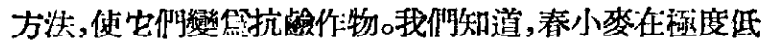

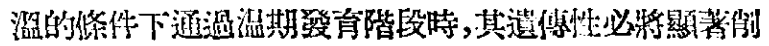

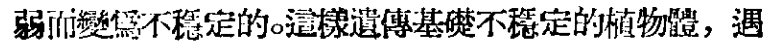

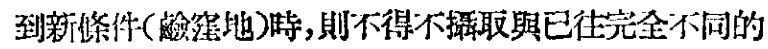

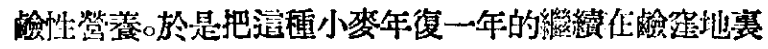
播㹴, 我們便能使其每一新生後代生長於这些新 條件

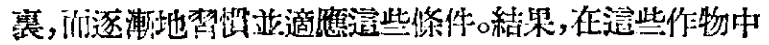

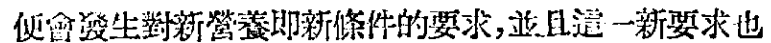

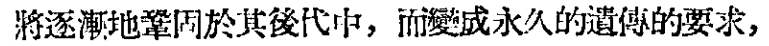

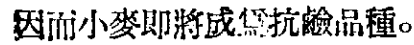

筇此,我們還售用了另一種方法：在一月寒使兩理

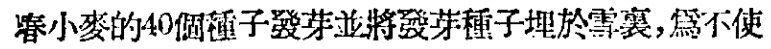

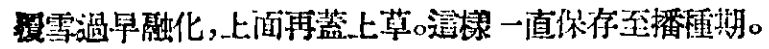

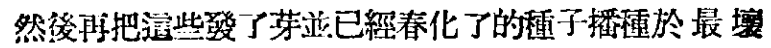

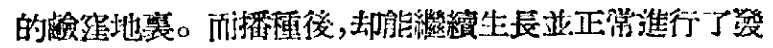

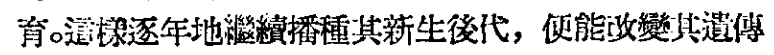
珄。

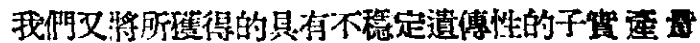

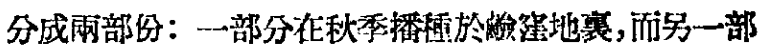

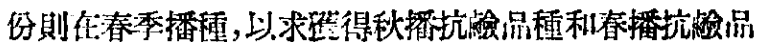

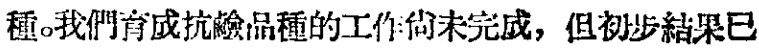
給子了我椚造成目的之信心。

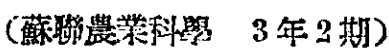

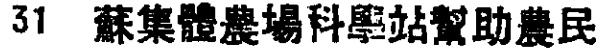 甚大}

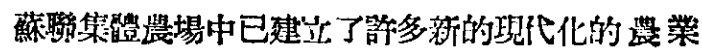

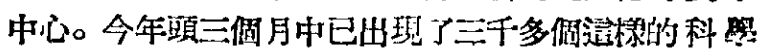

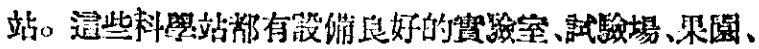

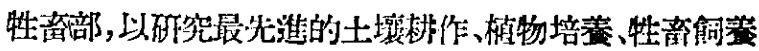

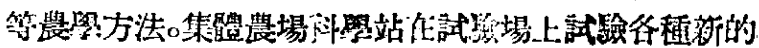

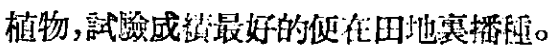

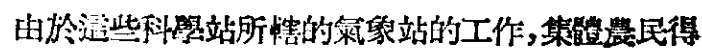

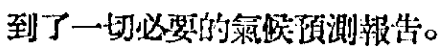

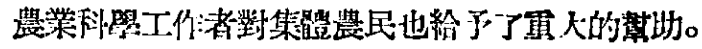

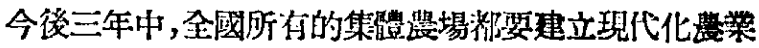

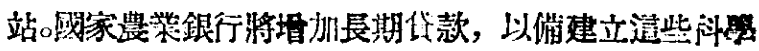

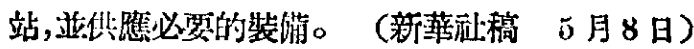

\section{2 藍聯一歷史悠久的植物園工 作人員在各地佈置果樹園}

全國最老的科罗研究機關之一一一位於克里 米亚

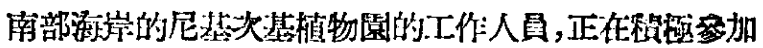

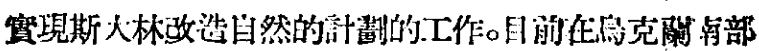

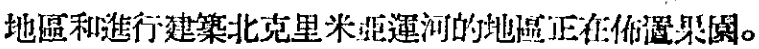

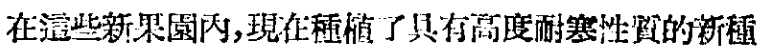

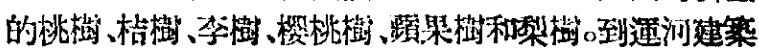
工程完成的時候,新然園将要出洼第一批果子。

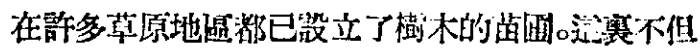

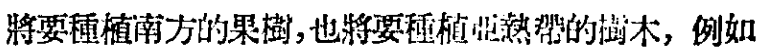

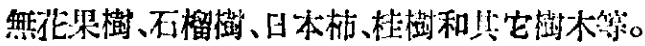

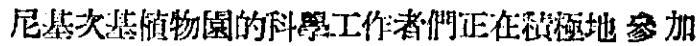

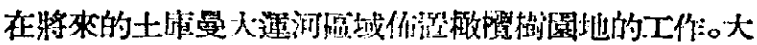

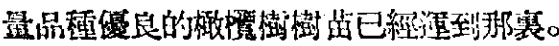

$$
\text { (新華泟稿 4月27日) }
$$

\section{醫藥衛生}

\section{3 口吃病的治療}

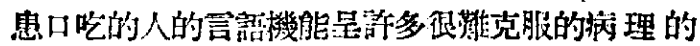

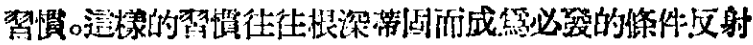
性,語䇺表現。

歷來所使用的一切治療方泩都不是絕對存效的。

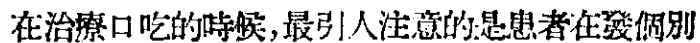

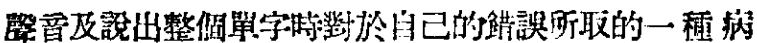

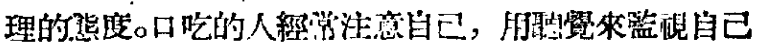

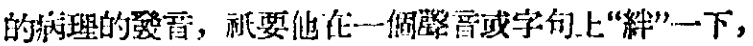
言語的障磪就而形加剴。 
由此可見除了引起口吃病的主要族理因子之外,其 中遗有非常寅要的反應心理因子一一患者本人對 其困

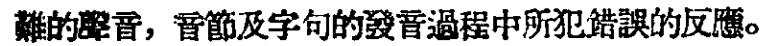

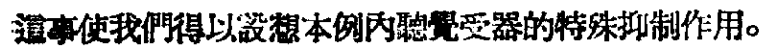

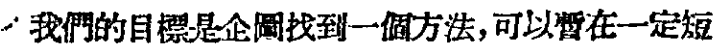

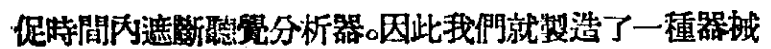
名叫 “發晋科正器” (Корректофои Correstophone)。 通個器械使患者不能注意自己的發曋並不断監視自己。 如此他就渐渐恢復正常的語言方式了。

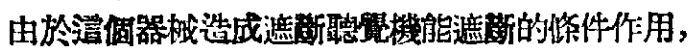
無形中在患者方面權成了完差的正常語言。此侍發晋较

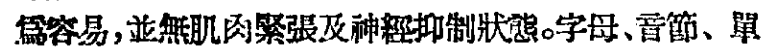
宇速接容易、發晋清管，同時語言有表情、面滑性、所有

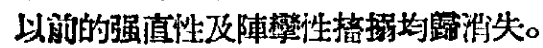

於是也構成了正確的呼吸節律,完羍的節律性脉搏 及各上氣道粘膜的正常的潄閏度。

根搭我們的觀察的大量传例，均浸見了本法的高度

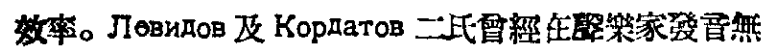
力 (Phonasthenia) 場合憵用本法收到很㙷著的效果。

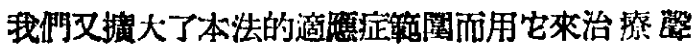

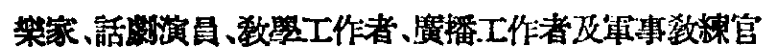
的整夏易波知性。

維渦多年該方面的工工作，我們得以製成更加改良的 利用不同電源的音科正器( 普通電流或乾電池)。

兩根附有插頭的橡皮管插入兩側外㙏道內；等到其

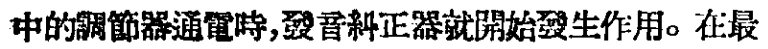

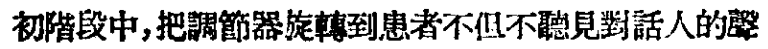

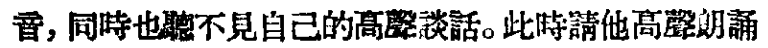

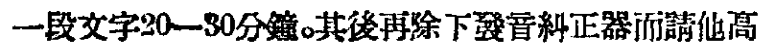

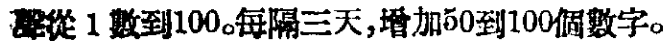

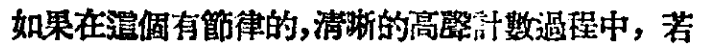

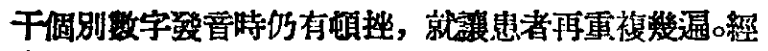

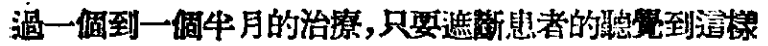

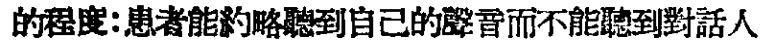

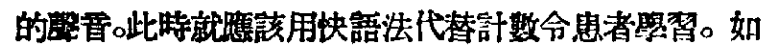

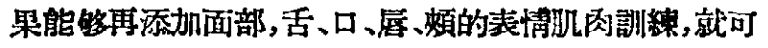
以構成一種複合治㞠。

在住院佟件中，治撩過程跑三個月;在阴診條件中， 逪调期限加倍。

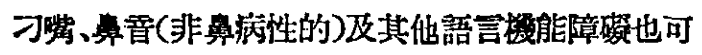
以用本法治療,磼得良好效率。

$$
\text { （蘇聮繁罳 } 7 \text { 年 } 4 \text { 期） }
$$

\section{4 先費的齿科救助}

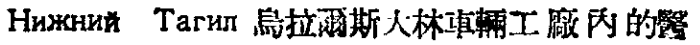

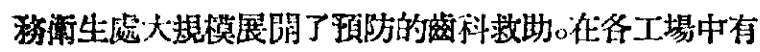

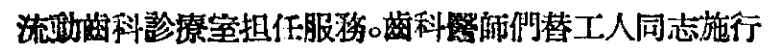
各種㟧牙的衛生處置。

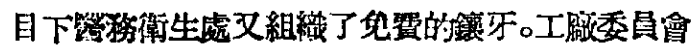

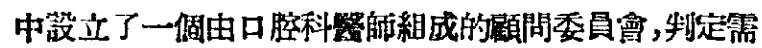

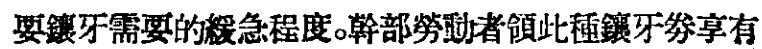
捗先鹳。

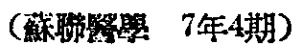

\section{F化合物一一第三種痛風劑}

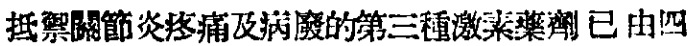

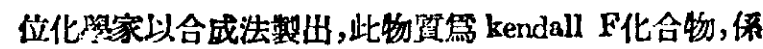
1930年第一次由副腎腺皮盗腺游陮而得。

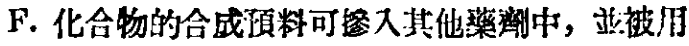

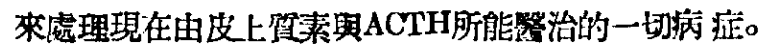

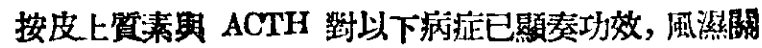

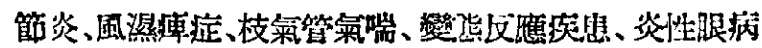
以及皮甪病等。

F化合物的重要性是當它被用來虑理病想者時，缺 憄者伦害性的間接影留比皮上資素來得更少。按国化合

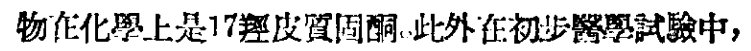

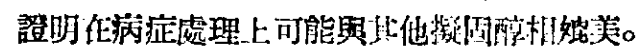

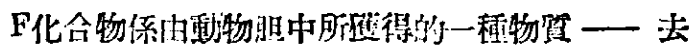
氧胆酸,其合成法比皮上算穼合成物要多雨次化祭上的 程序。 (Science News Letter 1951.1.6.)

\section{6 十分少見的長害}

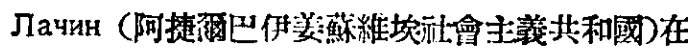
Лачинский 高] ᄂ地䗝 Шалва 村中, 居民Ибрагим Гап-

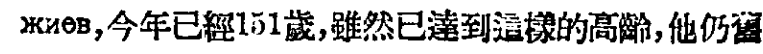
相當煡康。

他的家庭中大小約有50多口人。

(蘚然祭等 7 年4期)

\section{7 別特羅娃獎金}

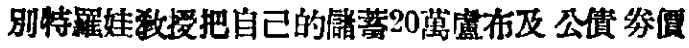

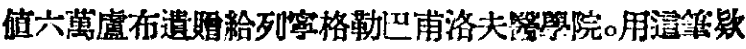
子及利息每年對於在內科㩆及精神神程病照方面 完成

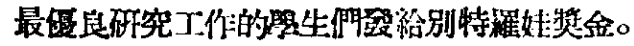

本年度得到別特羅娃族金的有 И. Чинка, А. Ли чко, А. Салимьянова及И.Мягкая.

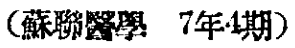

\section{社 會 科 學}

\section{8 世界上最大的大學}

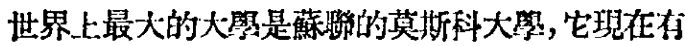

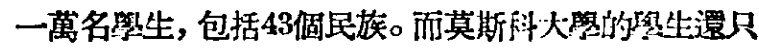
佔全莫斯科古大祭生的 $1 / 13$ o莫斯科市洪行大罢生 135 ,

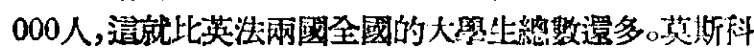
大照在列察山上修建的新校舍将於今年內艺工，它将成

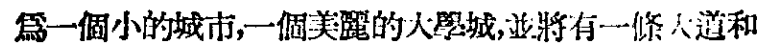

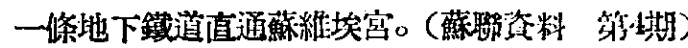

\section{9 蘇科學院討論中國語文研究 的問題}

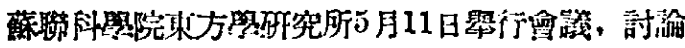
斯大林路於票言壆的著作和中国語文砄究的基本間題。

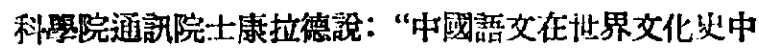




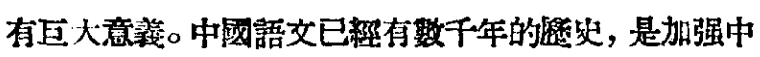
國人民內部国結的强有力的工具。毛澤東著你菂出版, 斯大林著作被臎成中文,都表明了最重要的理険文章用

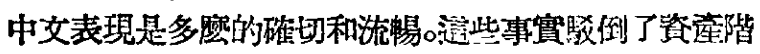

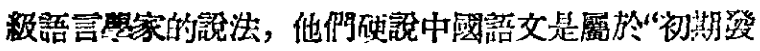
展體系”的语文,是無定形的語文。蘇聯學者在斯大林關

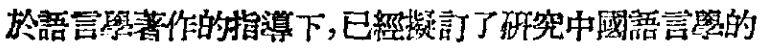

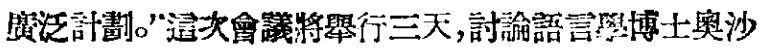

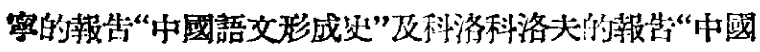
語女的現狀”。

(新靯刑稿 5 月14日)

\section{0 蘇联科學院人種學博物館附 設朝鮮陳列所開放}

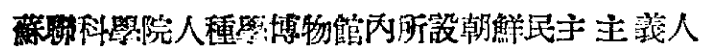

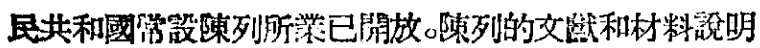

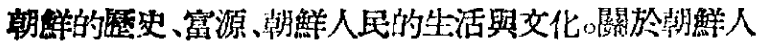

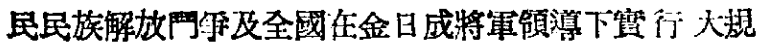
模民主改革的展篦品、都陳列在專門的陳列室內。

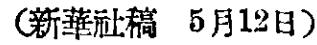

\section{1 國際民主法學家協會}

國際民主法家家協會, 曾於1950年11月23至24日在

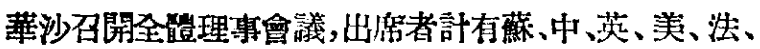
意、波、印、伊的和南美國家等國的代表。中國由錢端升

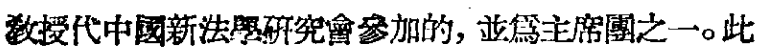
國際團體的理事會主演是普利特(英),副主管是德拉契 納(奏)，秘書長是諾德曼(法)，副秘書長是莫斯加(波)。

(人民日報 4 月14日)

\section{2 錫淢國立博物舘1948一-49年 年報}

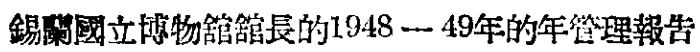

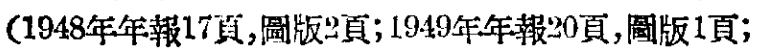

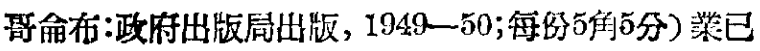

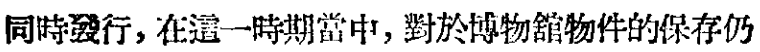

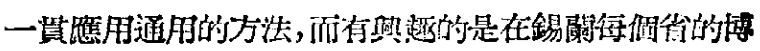
物管中已經開始蒐集活的動物了, 和其他的國立博物舘

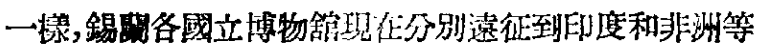
地從事各項探集工作。（Nature Vol.166 No.4:333.)

\section{3 日本法隆寺壁棗付之一炬}

日本著名的古代壁畫，代法隆寺金堂內有12幅，(份

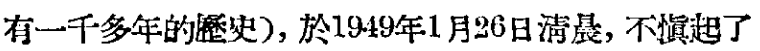
火贸，12幅占代壁畫完全付之于炡，日本民主主義科學

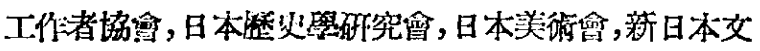
隐會. 新建筑家距合會, 國立博物舘職工會等民主交化

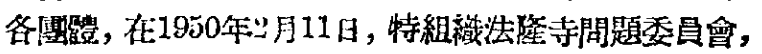
進行討論囱個重大的問題。

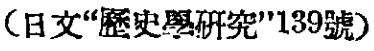

\section{4 日本科學界組成調查團研究 古代秀衡遗體}

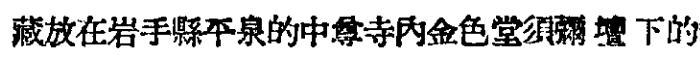

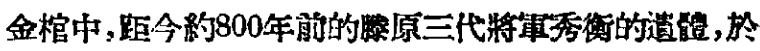

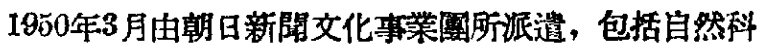

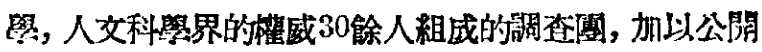
綜合的铜查，並使用X光及作其他的科學的究。现已隻得 等多贵重的發現; 如墐次於正倉院所藏的占代的“裙”、

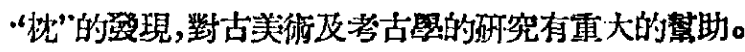

(文物參考䜤料 獍3期)

\section{5 布加勒斯特的圖書舘建設}

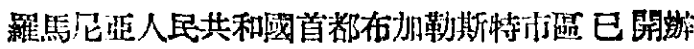

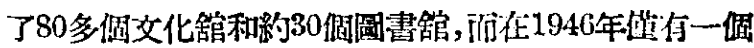

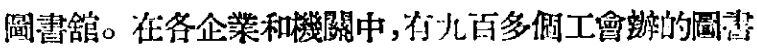

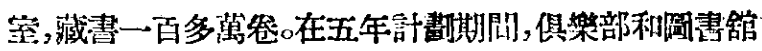

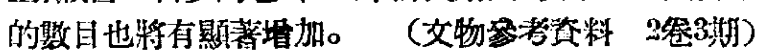

\section{6 在美帝奴役下日䞶裹落的日 本圖書舘}

日本自戰败投降後，在美帝奴役和吉田政府的反動

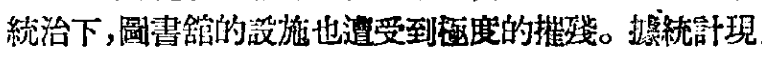
在全國共有圆湆舘的 1,5050 所; 其中清書數在 3,000 册以

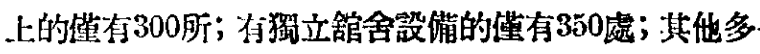

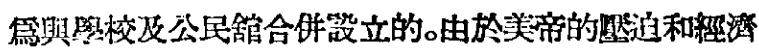

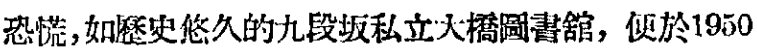

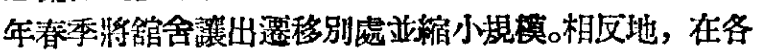

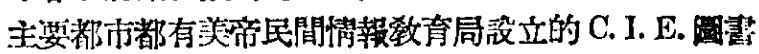

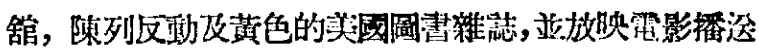
唱片等，以之麻醉日本人民。吉田反動政府踓於1950年4 月制訂並会侑了新的圆畫舘法，企圖加以革激，但由於

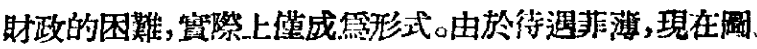

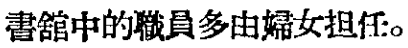

（文物參考資料 决很3期）

\section{7 日本學術界公開研究金堂焚 㷷後殘存秘实}

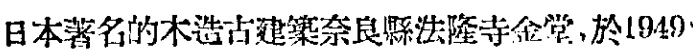

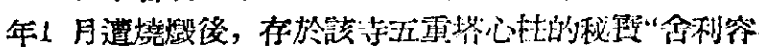

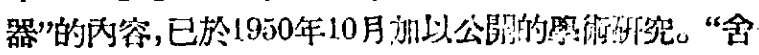

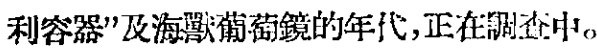

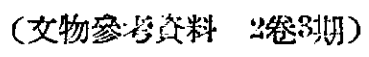

\section{8 日本古建築迭造火災焚㨬}

維著名的木造古建筑法隆寺金堂發生火多之後,日

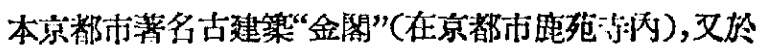
1950 年 7 月黎明發生火災。該閣係距今 350 年骨角，日本足

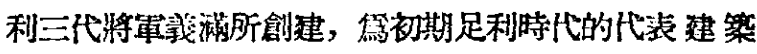

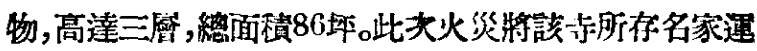

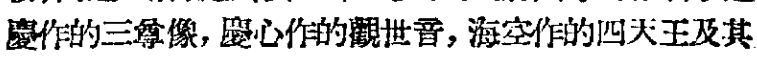
他貴重的古代美衔品全部燒微。

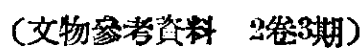

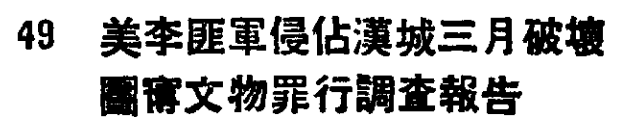




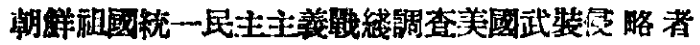
目李承晚韭帮暴行委員會，於1951年3月1日向聯合國本

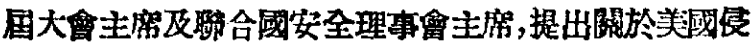

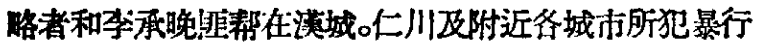
的第四號調查啹告。關於圆書舘，博物院文物破壊部分

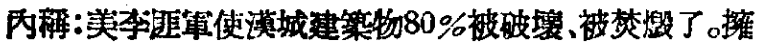

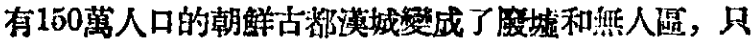

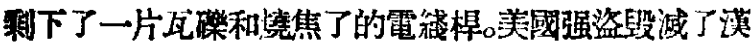

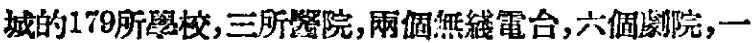

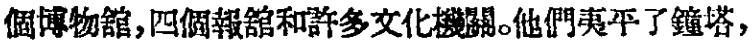

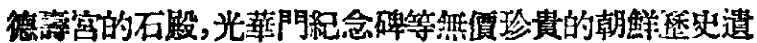

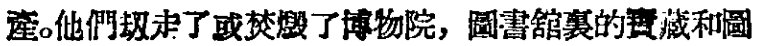
嘾珍本。

（交物栄考資料 2尞3期）

\section{0 美帝在國內大量焚概進步書}

\section{籍}

美國反動的統治者正在空息着民族解放運犟力，他們

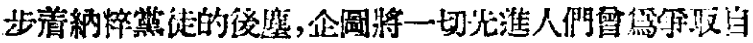

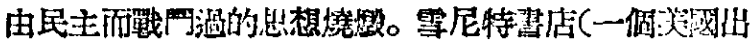

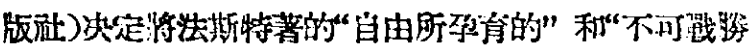

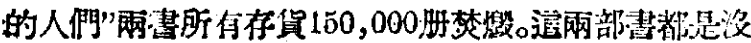

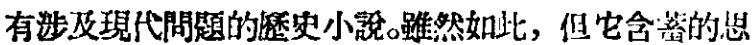
想，在最反動的“非美活動委員會”看來，却题如此的他

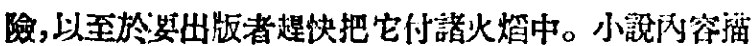

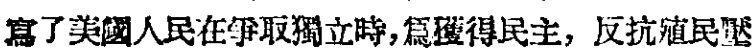

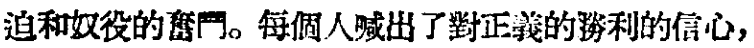

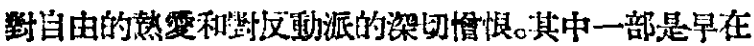
1939年問世,另一部是结194年。

（文物美考凟料 2得3期）

\section{1 土耳其反動政府下令沒收俄 羅斯古典文學名著}

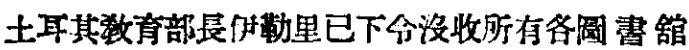

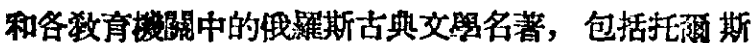
薮、高爾基和哭訶夫的藷作。

（女物学资資料 2然3期）

\section{科學界動態}

\section{2 世界科協基行第二届代表大 會}

世界科的工作诸坫會，於4月10日迪在巴黎舉行第 二国代表大青。

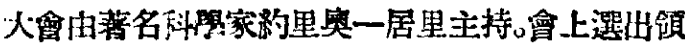

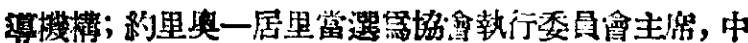

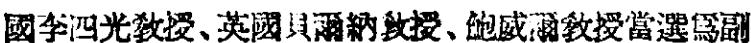
主管。

大會已通過决筑，蓝發表了告世界科學工作者書及

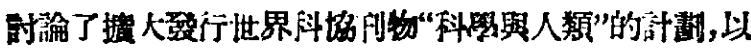

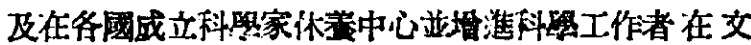

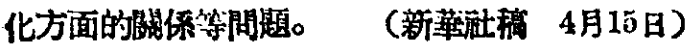

\section{3 羅馬尼亞人民共和國科學院 會議}

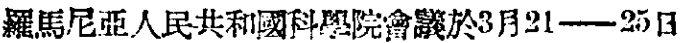

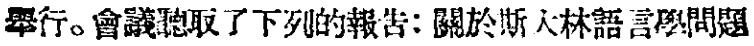

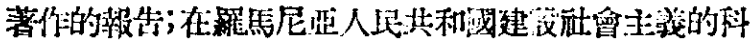

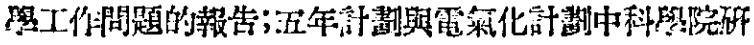
究機閵1951年的补劃的報告。

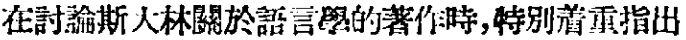

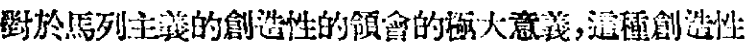

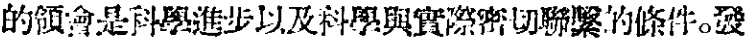

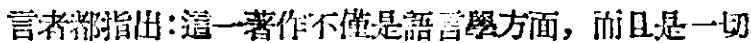

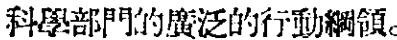

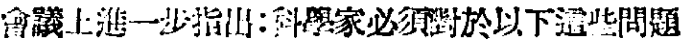

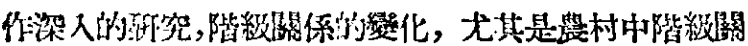

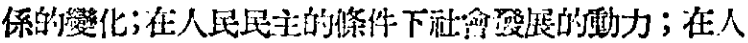

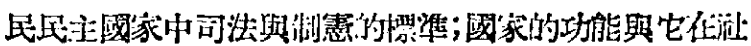

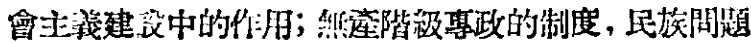

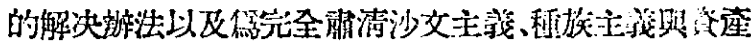

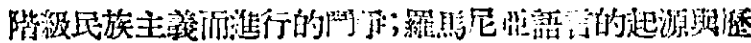

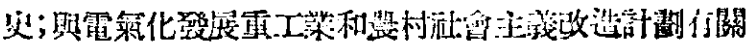
的海多科等問題。

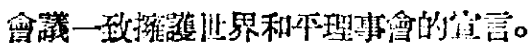

（宇抆持人和平，等抆人民主 中交版No.86)

\section{4 烏克蘭科學院里沃夫分院}

3 月31日舉行了一次勧沃夫州科學工作人員, .工業

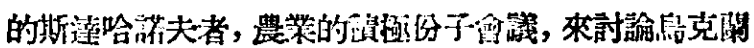
共和淢的姆院分院在盟沃夫的成立。

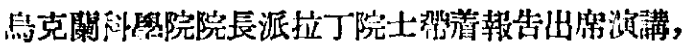

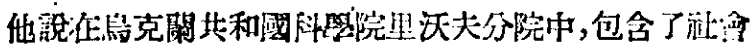

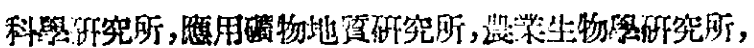
機放和自動機践呼究所。

，点克籍科祭院分院在橗沃夫的建立，將要促潐鳥克

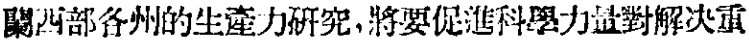

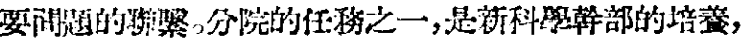

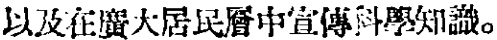

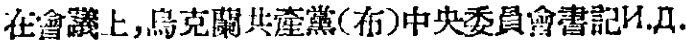

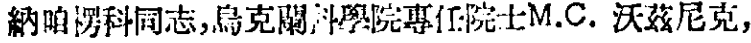

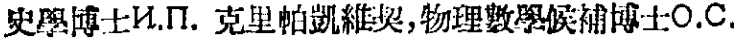

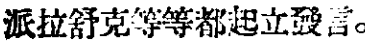

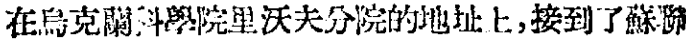

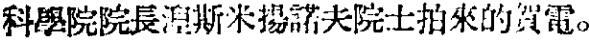

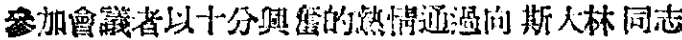
致敬

（眞理報 4月1日）

\section{5 布拉格舉行國際和平獎授 獎典禮}

右拉格於4月17日藇行了國際和平楚全授了捷克斯

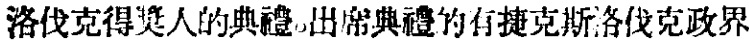

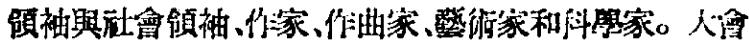

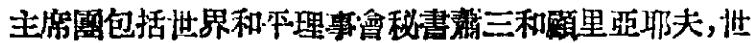




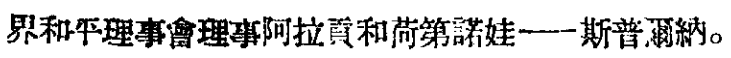

會上首由荷第藷娃一一斯普河納代表 世界和平理

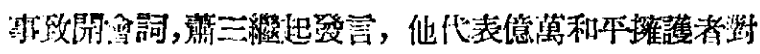

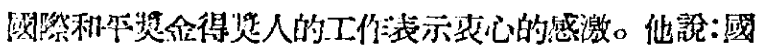

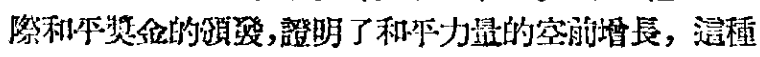
才盐能够面们且必特阻止戰尔。

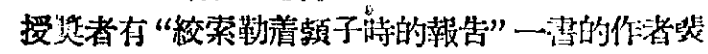

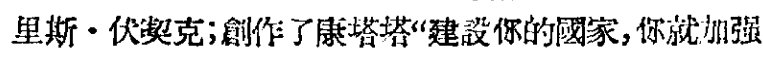
了和平”的作助家多比留斯。

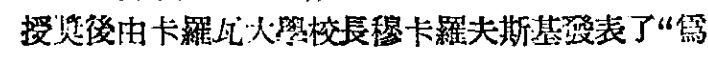
和平面临和的交化”的報告。

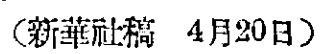

\section{6 約里奧・居里就噟獎事發表 談話}

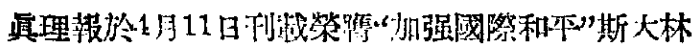

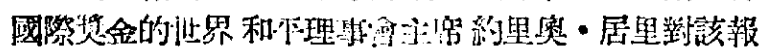

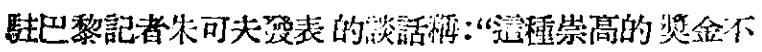

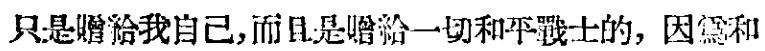

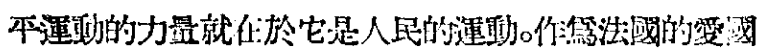

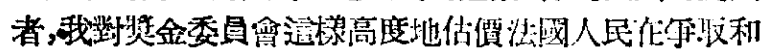

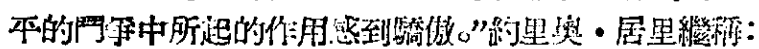

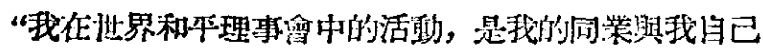

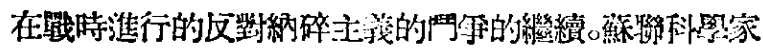

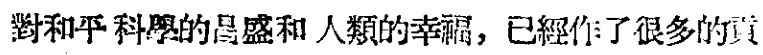

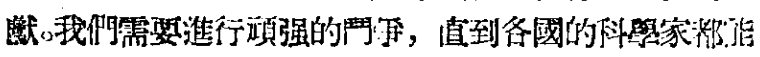

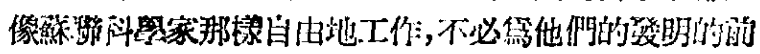

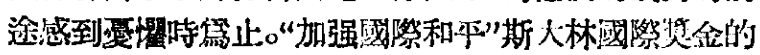

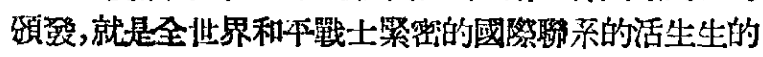
毁微”。

約里奥・居里 評論治國政府泊害 低界和平理事會

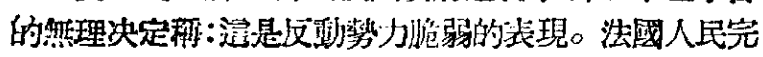

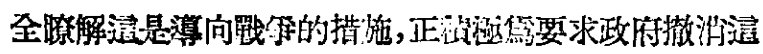

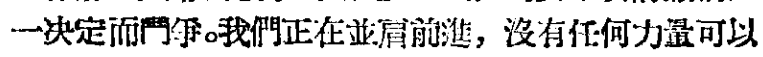

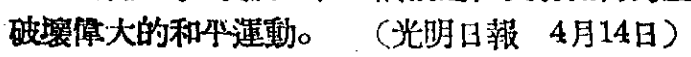

\section{7 落聯紀念巴夫洛夫逝世十五 遇年的科學會議}

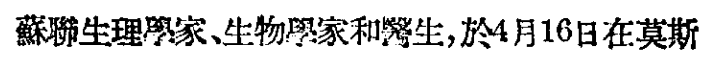

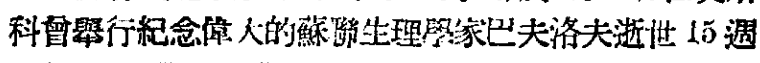
年的會燨。現已閉募。

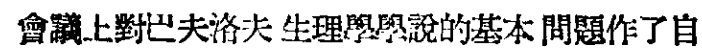

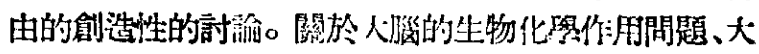

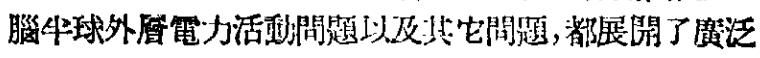

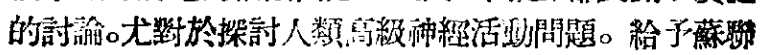

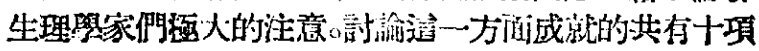

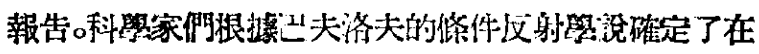

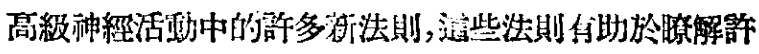

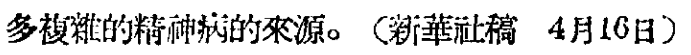

\section{8 瓦維洛夫院士的科學逗産}

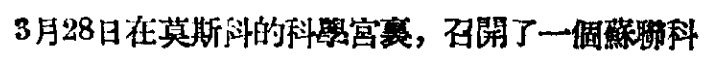

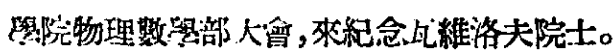

部的院士士秘書彼得篗夫斯息, 强䦖着瓦維洛夫著作 的经球僬值。

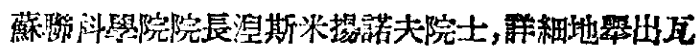
維洛夫院士之有成效栭多方面的事業特溦，欲明他在葆

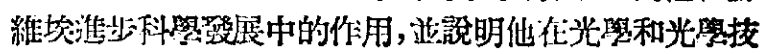

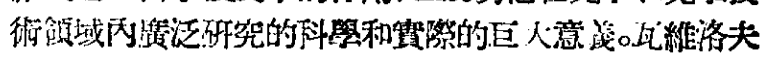

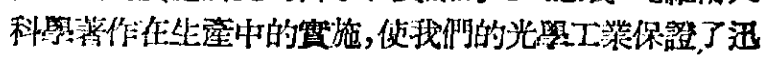

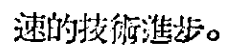

台列萗院士然着關於瓦維洛夫院士 佂物理領域队

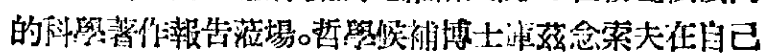

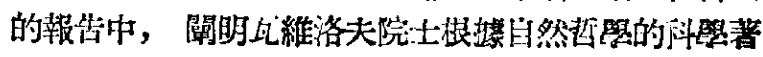
作。

(置理赫3月年日)

\section{9 蘇聯著名漢學家亞列克塞耶 夫逝世}

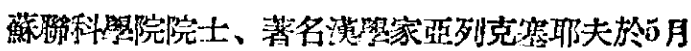

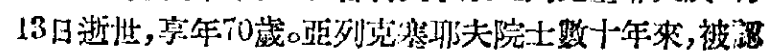

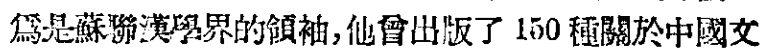

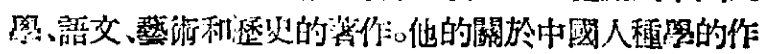

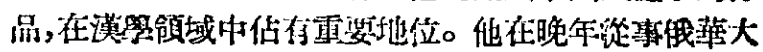

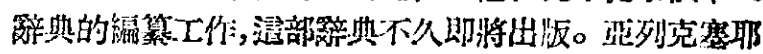

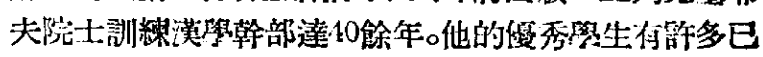

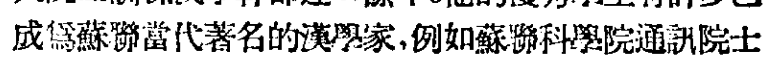
康拉德,奧沙蜜致授,艾德林等。

（新華社稿 5月14日）

\section{0 日本中央氣象台台長藤原博 士病逝}

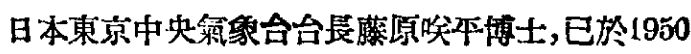

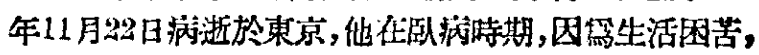

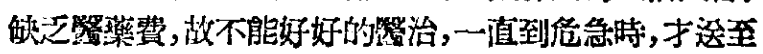

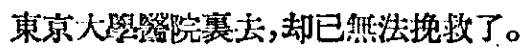

$$
\text { (日本“科忽”20隹 12期) }
$$

\section{1 日本中央科嶨研究所所長仁 科博士病逝}

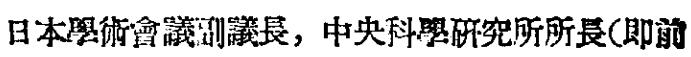
理化照旺究所), 仁科芳雄博士於1951年1月10日病逝, 他是日本研究宇宙路,原子能的整家，是日本原子核物

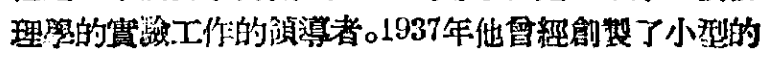
迴旋加速器 (Cyclotron), 1938年6月㛊始䌘造大型的迥

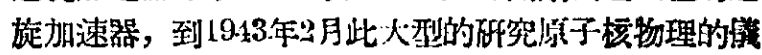

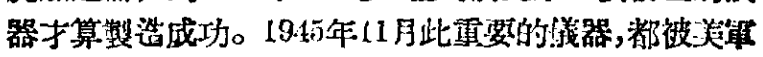
毁淖了，狺對日本物理罢界的損失，以及仁科芳雄本人 的心境的打慗是積人的,最後他終於寂寞的苦悶的在困 難的生活重監下落逝了。

(日文“科緊”21管 4 期)

\section{2 日本東京大學教授拒絕接 受研究軍事科學}

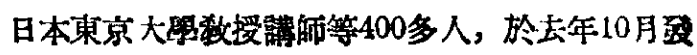
第六期
o
科學通報
- 689 . 


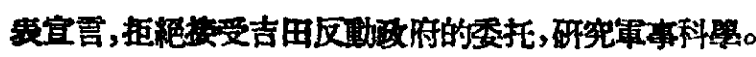

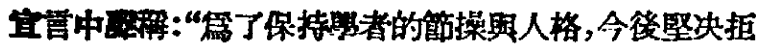

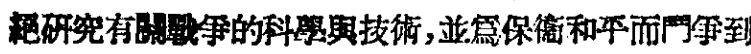
实"。

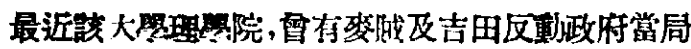

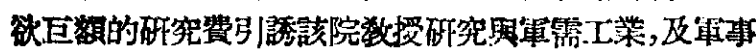

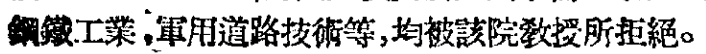
（日交“民主新聞”4月21日）

\section{3 日本北海道大學反對美籍教 授}

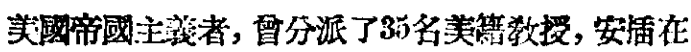
日本各大學，從事文化侵略活動。日本北海道大䀾，也被

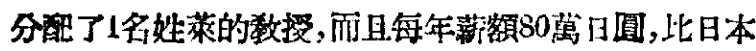

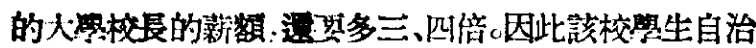

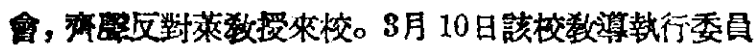

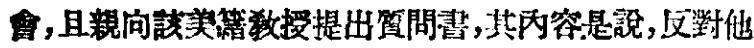

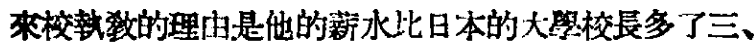
四管，以他的落額，該校可多聘四、五位日本名敉授了。

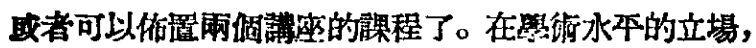
美國人和日本人也不㲥有如是的差別的。

$$
\text { （日交“民主新閩”5月1日） }
$$

\section{4 鐵托南斯拉夫學生們的困難 處境}

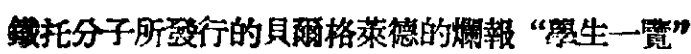

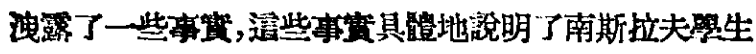

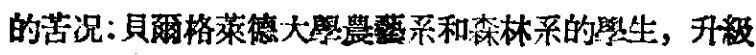
的只佔 $40 \%$ ，留粐的佔 $30 \%$ ，其馀的全都影了學;偳完第 一貫年的課程的只有 $30 \%$ ，没有及格的有 $20 \%$ ，其餘的 都放萧了課程。

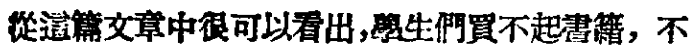

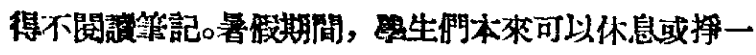

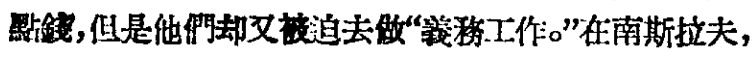

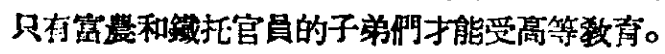

(争取持久和平，争取人民民主，中交版No.86)

\section{出版消息}

\section{5 藮聯紀念出版第}

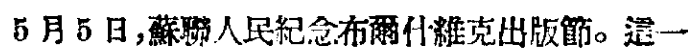

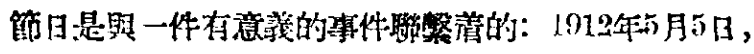

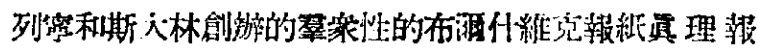

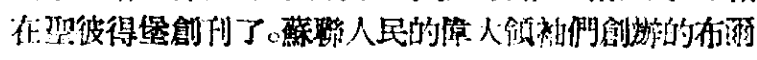

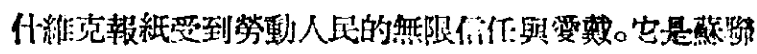

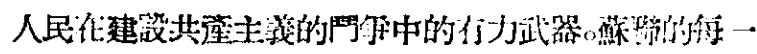

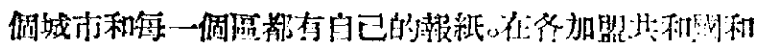

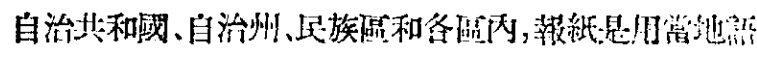

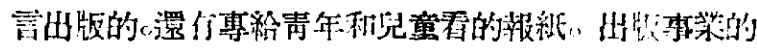

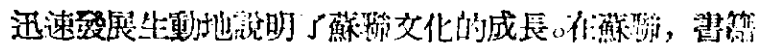

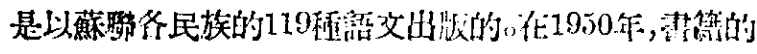

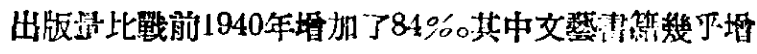
加了三倍。钎多俄國和怈界的古典名著、蘇职们家的作:

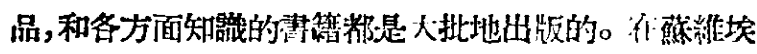

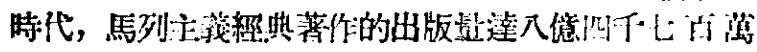

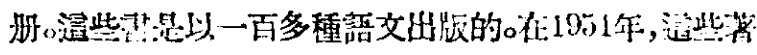
作出版的数目將增加 $31 \%$

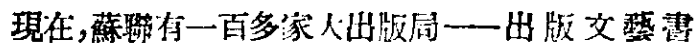

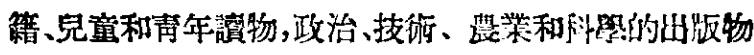
等等。

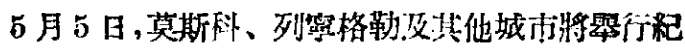

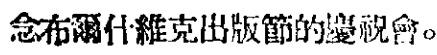

$$
\text { (新萧动稿 } 5 \text { 月9日) }
$$

\section{6 英國出版關於蘇聯䢖傳學的 曾及小册子}

最近英國出版了一本介紹“李森科論作”的小掤子， 書名是“李森科是對的”, 作者是吉姆斯 - 法菲 (Jnmes

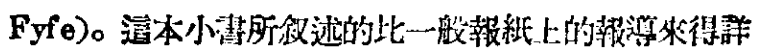

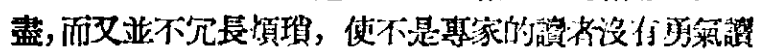

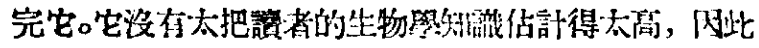

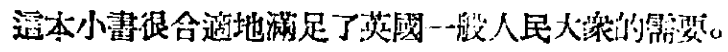

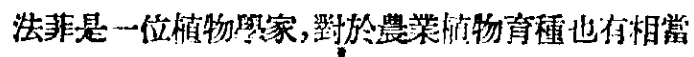

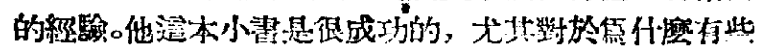

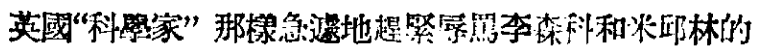

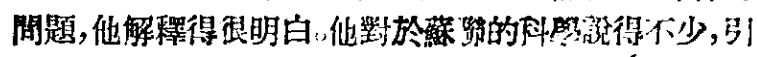

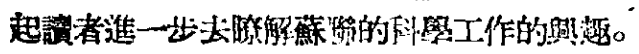

(Labour Monthly March 1951)

\section{來 函 照 登}

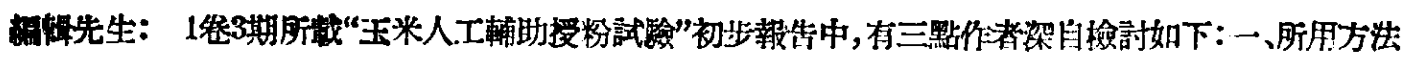

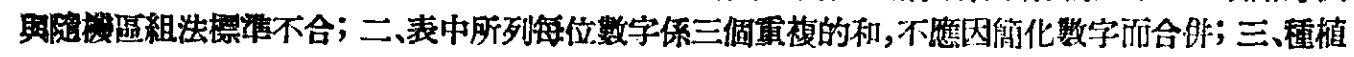

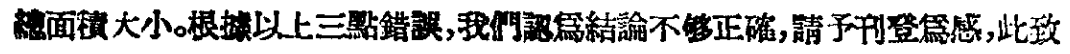
敬福

\section{余惄﨎謹辟}

